\title{
ORIGINAL ARTICLE Role of the adipose PPAR $\gamma$-adiponectin axis in susceptibility to stress and depression/anxiety-related behaviors
}

\author{
$\mathrm{M} \mathrm{Guo}^{1}, \mathrm{CLi}{ }^{1}, \mathrm{Y} \mathrm{Lei}^{2}, \mathrm{~S} \mathrm{Xu}{ }^{1}, \mathrm{D}$ Zhao ${ }^{1}$ and X-Y Lu${ }^{1,2,3}$
}

\begin{abstract}
Adaptive responses to stressful stimuli involving behavioral, emotional and metabolic changes are orchestrated by the nervous and endocrine systems. Adipose tissue has been recognized as a highly active metabolic and endocrine organ, secreting adipokines that operate as hormones to mediate the crosstalk with other organs including the brain. The role of adipose tissue in sensing and responding to emotional stress and in behavioral regulation, however, remains largely unknown. The nuclear receptor peroxisome proliferator-activated receptor gamma (PPARY) is a key transcriptional factor controlling adipokine gene expression. Here we show that chronic social defeat stress decreases messenger RNA and protein levels of PPARY in adipose tissue of susceptible but not resilient mice, which was correlated with social avoidance behavior. A corresponding reduction in adipose adiponectin

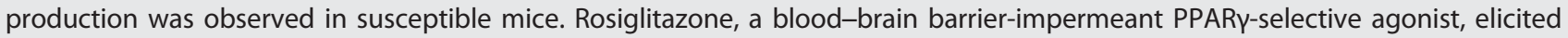
antidepressant- and anxiolytic-like behavioral effects in wild-type mice, with a concurrent increase in plasma adiponectin levels. These effects of rosiglitazone were absent in mice lacking adiponectin but having normal PPARy expression in adipose tissue and brain. Moreover, pretreatment with the PPARy-selective antagonist GW9662 blocked rosiglitazone-induced adiponectin expression and antidepressant/anxiolytic-like effects. Together, these results suggest that the behavioral responses to rosiglitazone are mediated through PPARy-dependent induction of adiponectin. Our findings support an important role for the adipose PPARY-adiponectin axis in susceptibility to stress and negative emotion-related behaviors. Selectively targeting PPAR $y$ in adipose tissue may offer novel strategies for combating depression and anxiety.
\end{abstract}

Molecular Psychiatry (2017) 22, 1056-1068; doi:10.1038/mp.2016.225; published online 13 December 2016

\section{INTRODUCTION}

Clinical evidence indicates that depression and anxiety disorders are heterogeneous in their phenomenology, etiology and treatment responses. There is a strong association between these emotional disorders and metabolic syndrome. ${ }^{1,2}$ However, the underlying biological mechanisms remain to be established. Responses to environmental challenges involve complex interactions between the nervous and endocrine systems. White adipose tissue, previously viewed as a passive organ for energy storage, is now recognized as an active metabolic and endocrine organ. It secrets a number of hormones, termed adipokines, that exert pleiotropic physiological functions. ${ }^{3}$ Adipose tissue dysfunction causes aberrant production and secretion of adipokines, which is known to contribute to the pathogenesis of metabolic syndrome. ${ }^{3}$ Some adipokines are able to cross the blood-brain-barrier (BBB), mediating the crosstalk between adipose tissue and brain through modulating neuronal excitability, synaptic plasticity and contributing to neural circuit remodeling. ${ }^{4-13}$ Although much is known about the regulation of adipose tissue function and adipokine production by metabolic states, little is known of the role of adipose tissue in behavioral responses to emotional stress and how adipokine production is regulated under stress conditions.

Peroxisome proliferator-activated receptor gamma (PPARY) is a ligand-activated transcription factor that belongs to the nuclear receptor family. ${ }^{14}$ It exists in two isoforms, PPARY1 and PPARY2, which are generated from the same gene by alternative splicing. ${ }^{15}$
PPARY1 is abundantly expressed in adipose tissue but also found in other tissues, whereas PPARY2 is restricted to adipose tissue. ${ }^{16}$ PPARY is essential for the formation of adipocytes; ${ }^{17,18}$ mice null for the PPARy gene are completely lacking adipose tissue. ${ }^{18}$ PPARy plays a key role in gene expression of adipokines. ${ }^{19-21}$ Adiponectin is the most abundant adipokine in the circulation and exclusively secreted from adipose tissue. ${ }^{22,23}$ Thiazolidinediones, synthetic ligands of PPARy including rosiglitazone and pioglitazone, induce the adiponectin promoter activity and increase adiponectin expression in adipocytes, which parallels elevated adiponectin levels in the circulation. ${ }^{19,24-26}$ These effects of thiazolidinediones can be blocked by the selective PPARy antagonist GW9662. ${ }^{27}$ PPARY agonists are widely used to treat type 2 diabetes through improving insulin sensitivity, ${ }^{28}$ which is partially mediated through induction of adiponectin. ${ }^{29,30}$

We have previously shown that adiponectin levels are decreased by chronic social defeat stress, ${ }^{31}$ an animal model of depression, post-traumatic stress disorder and other anxietyrelated disorders. ${ }^{11,31-34}$ Adiponectin insufficiency increases susceptibility to social defeat stress, and intracranial administration of adiponectin reduces depression- and post-traumatic stress disorder-related symptoms. ${ }^{9,31,35}$ However, whether its upstream positive regulator PPARY in adipose tissue participates in mediating susceptibility to stress and emotion-related behaviors remains to be elucidated. In the present study, we investigated the effects of chronic social defeat stress on adipose PPARY

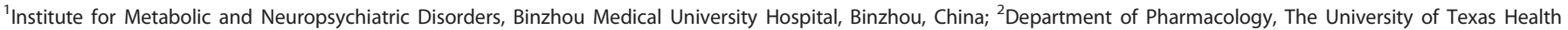

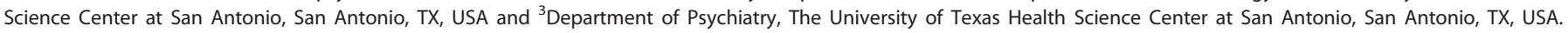
Correspondence: Dr X-Y Lu, Department of Pharmacology, University of Texas Health Science Center at San Antonio, 7703 Floyd Curl Drive, San Antonio, TX 78229, USA. 
expression and its relationships with adiponectin production and stress vulnerability. This stress model was selected as socially defeated mice can be segregated into stress-susceptible and stress-resilient subpopulations based upon their social interaction behavior, ${ }^{32,33}$ which provides a valuable system to study the molecular basis of susceptibility and resilience to emotional stress.

a
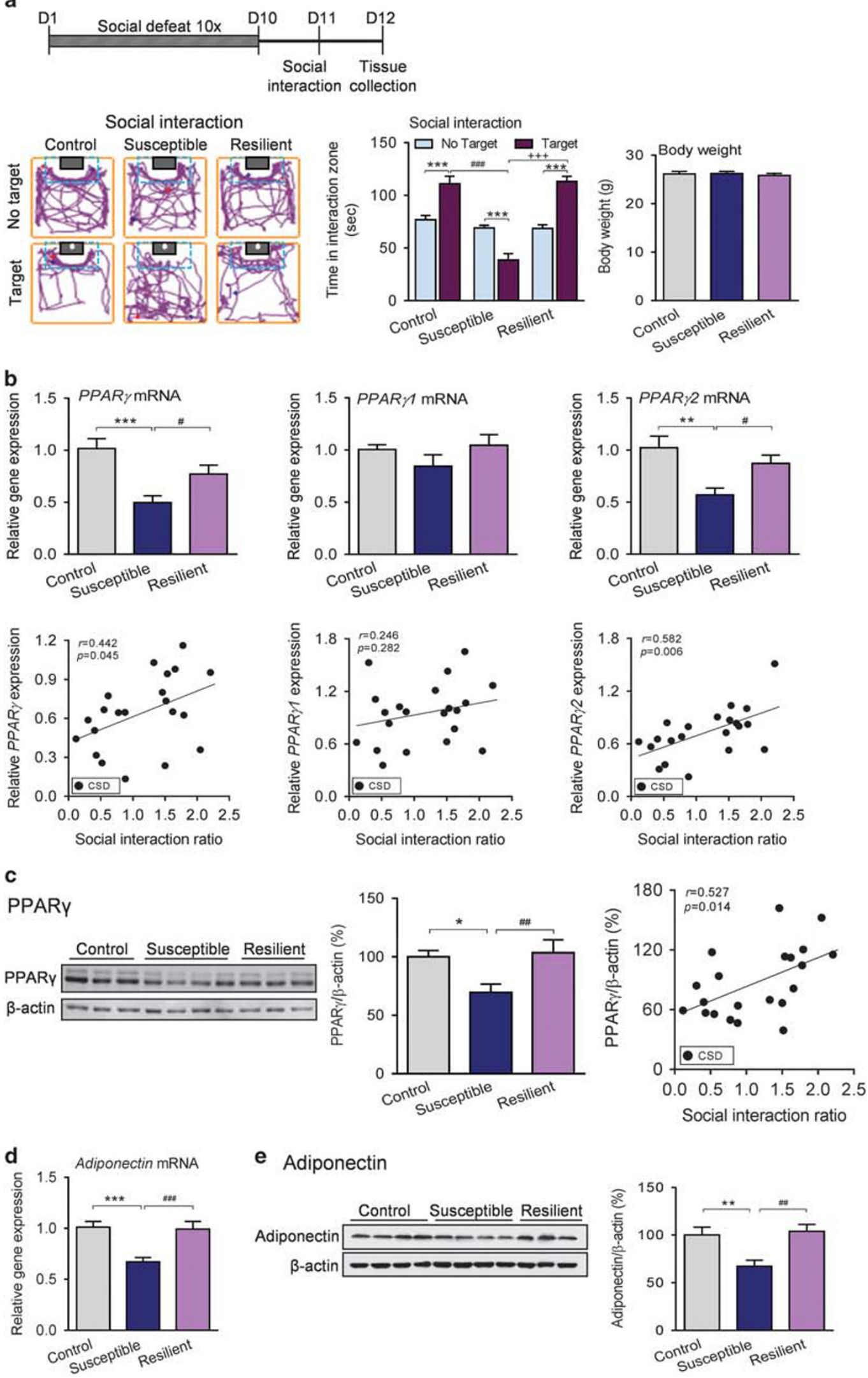

e Adiponectin
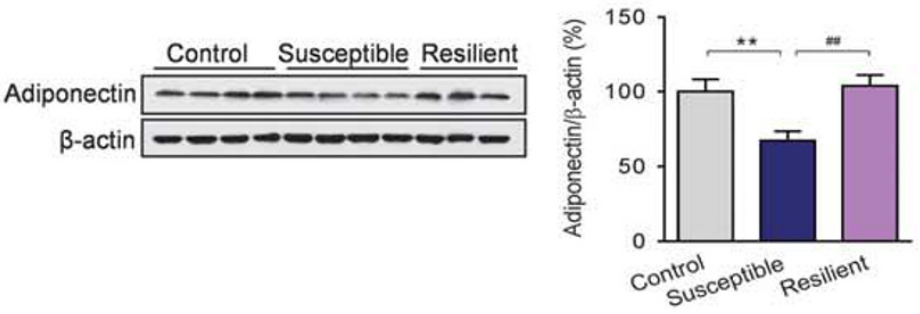

Figure 1. For caption see page on 1058. 
We further examined whether activation of PPARy by peripherally administered rosiglitazone, a BBB-impermeant PPARy agonist, is capable of producing antidepressant- and anxiolytic-like effects within a relatively short-time frame, and whether the presence of adiponectin is required for behavioral responses to rosiglitazone. We found that chronic social defeat decreased adipose PPAR $y$ and adiponectin production in susceptible mice but not in the resilient subpopulation. Activation of PPARy produced antidepressant- and anxiolytic-like effects through an adiponectin-dependent mechanism. These results indicate an important role for the adipose PPARYadiponectin axis in stress responses and emotion-related behavioral regulation.

\section{MATERIALS AND METHODS}

\section{Animals}

Male and female wild-type C57BL/6J mice were purchased from Jackson Laboratory and maintained a breeding colony. CD1 mice were purchased from Vital River Laboratory Animal Technology (Beijing, China). Heterozygous adiponectin knockout $\left(\right.$ Adipo $^{+/-}$) mice were originally obtained from Dr. Philipp Scherer (UT Southwestern, Dallas, TX, USA) ${ }^{29}$ and backcrossed on the C57BL/6J background for more than 10 generations. $\mathrm{Adipo}^{+-}$mice were intercrossed to generate homozygous mutant offspring and wild-type littermates. Mice were housed in a 12:12 h lightdark-cycle (light on at 0700 hours) with ad libitum access to food and water. Male mice at 8-12 weeks of age were used for the experiments. All animal procedures were approved by the Institutional Animal Care and Use Committee at Binzhou Medical University Hospital and the University of Texas Health Science Center at San Antonio.

\section{Drugs}

Rosiglitazone potassium salt (Cayman Chemical Company, Ann Arbor, Ml, USA) was dissolved in normal saline $(0.9 \% \mathrm{NaCl} w / \mathrm{v})$ before use. For acute treatment, a single intraperitoneal (i.p.) dose of rosiglitazone $(10 \mathrm{mg} / \mathrm{kg}$ ) was given to mice $1 \mathrm{~h}$ or $3 \mathrm{~h}$ before collecting blood and adipose tissue samples or performing behavioral tests. For multiple treatments, mice were given three i.p. injections of rosiglitazone $(10 \mathrm{mg} / \mathrm{kg})$ either once daily over 3 days or 3 times within $24 \mathrm{~h}(23.5 \mathrm{~h}, 3 \mathrm{~h}$ and $1 \mathrm{~h})$; the last injection was given $1 \mathrm{~h}$ before collecting blood and tissue samples or behavioral testing. The dose of $10 \mathrm{mg} / \mathrm{kg}$ rosiglitazone for i.p. injection was chosen based upon its effectiveness in improving insulin tolerance in mice. ${ }^{25}$ The selective PPARY antagonist GW9662 (Sigma-Aldrich, St. Louis, MO, USA) were dissolved in dimethyl sulfoxide, diluted to a final concentration of $0.2 \mathrm{mg} / \mathrm{ml}$ in $0.9 \%$ saline containing $1 \%$ dimethyl sulfoxide, and given i.p. injection ( $2 \mathrm{mg} / \mathrm{kg}) 30 \mathrm{~min}$ before administration of rosiglitazone or saline. This dose and timing of injection of GW9662 have been reported to block the actions of PPARy agonists. ${ }^{36,37}$ All mice were weighed before experiment and randomly assigned to different treatment groups.

\section{Chronic social defeat}

Social defeat was generated using a resident-intruder paradigm as previously reported with minor modifications. ${ }^{11,31,34}$ Adult male CD1 mice were co-housed with two female CD1 mating partners at least 3 weeks. Subsequently, male sexually experienced CD1 mice were housed individually for 1 week before being screened for aggression. During the screening process, a 'screener' C57BL/6J mouse was introduced into the cage of a singly housed CD1 mouse for $3 \mathrm{~min} / \mathrm{session}$ and three sessions/ day and the latency of the CD1 mouse to attack the 'screener' C57BL/6J mouse during each session was recorded. The screening procedure was repeated for 3 consecutive days. The CD1 mice with the attack latency $<60 \mathrm{~s}$ for at least two sessions on the last day were selected for use as resident aggressors in social defeat experiments. All aggressors were rescreened in three consecutive sessions to ensure aggressiveness of CD1 mice before use in subsequent social defeat experiments.

For the chronic social defeat procedure, male C57BL/6J experimental mice were individually placed into the home cage of an aggressive CD1 mouse for $10 \mathrm{~min}$ during which time the experimental mouse was physically defeated. Thereafter, the CD1 resident mouse and the C57BL/6J intruder were housed together but separated by a perforated plastic divider to allow visual, olfactory and auditory contact for the remainder of the 24-h period. C57BL/6J mouse was exposed to a new resident CD1 mouse and subjected to social defeat each day for 10 consecutive days. Control mice were housed two per cage in the cages identical to those used for socially defeated mice. Social interaction was assessed at $24 \mathrm{~h}$ after the last social defeat session, which was performed in a box $(40 \times 40 \times 40 \mathrm{~cm})$ with infrared light illumination. Each social interaction test consisted of two 2.5-min sessions. In the first 2.5-min 'no target' session, the C57BL/6J mouse was placed into the open arena with an empty wire mesh cage $(10 \times 6.5 \times 5 \mathrm{~cm})$ at the middle of one side of the box. For the second 2.5-min session with 'target', an unfamiliar CD1 male mouse was placed into the wire mesh cage. The time spent by the $\mathrm{C} 57 \mathrm{BL} / 6 \mathrm{~J}$ mouse in the 'interaction zone' $(25 \times 14 \mathrm{~cm})$ surrounding the wire mesh cage was measured. Social interaction ratio was calculated as time spent in the interaction zone in the presence of a social target divided by the time spent in interaction zone without a social target.

\section{Forced swim test}

Mice were placed into a clear Plexiglas cylinder $(25 \mathrm{~cm}$ in height and $10 \mathrm{~cm}$ in diameter) filled with water $\left(24^{\circ} \mathrm{C}\right)$ for a 15 -min pretest, followed $24 \mathrm{~h}$ later by a 6 -min forced swim test session. ${ }^{31,38}$ The latency to immobility and the duration of immobility during the pretest and in the last 4 min of the test were measured. Immobility was defined as no active movements except those required for respiration.

\section{Elevated plus-maze test}

This test is a widely used anxiety paradigm, which is based on the natural conflict between the drive to explore a new environment and the tendency to avoid a potentially dangerous area. ${ }^{39}$ The elevated plus-maze consisted of 4 arms (35-cm long and 5-cm wide) arranged in the shape of a 'plus' sign and elevated to a height of $70 \mathrm{~cm}$ from the floor. Two arms have no side or end walls (open arms) and the other two arms have side walls and end walls but are open on top (closed arms). The open and closed

Figure 1. Regulation of messenger RNA (mRNA) and protein levels of PPAR $\gamma$ and adiponectin in adipose tissue by chronic social defeat stress. (a) Upper, timeline of chronic social defeat procedure. Lower-left, schematic representation of the social interaction test. Lower-middle, time spent in the interaction zone with and without the target CD1 mouse (subgroup: $F_{(2,30)}=27.470, P<0.001 ;$ target: $F_{(1,30)}=22.281, P<0.001$; subgroup $\times$ target interaction: $F_{(2,30)}=45.329, P<0.001$. ${ }^{* * *} P<0.001$ compared with the absence of a social target, $\# \# \#$ \# 0.001 compared with the control group in the presence of a social target, ${ }^{+++} P<0.001$ compared with the resilient group in the presence of a social target. Lower-right, body weight of chronic social defeat stress mice on day $12\left(F_{(2,30)}=0.177, P>0.05\right)$. (b) Upper, mRNA levels of PPARY (left: $F_{(2,30)}=9.180, P<0.001$ ), PPARY1 (middle: $\left.F_{(2,30)}=1.399, P>0.05\right)$ and PPARY2 (right: $F_{(2,30)}=6.166, P<0.01$ ) in adipose tissue. ${ }^{* *} P<0.01$, $* * * P<0.001$ compared with the control group, ${ }^{*} P<0.05$ compared with the resilient group. Lower, correlation between mRNA levels of $P P A R \gamma$, PPARY1 and PPARY2 and social interaction ratio in mice subjected to chronic social defeat stress (left: $r=0.442, P<0.05 ;$ middle: $r=0.246$, $P>0.05$; right: $r=0.582, P<0.01)$. CSD, chronic social defeat. (c) Left, immunoblots of PPAR $\gamma$ proteins in adipose tissue. Middle, quantification of PPAR $\gamma$ protein $\left(F_{(2,30)}=4.943, P<0.05\right)$. Right, correlation analysis between PPAR $\gamma$ protein and social interaction ratio in CSD mice (Pearson correlation, $r=0.527, P<0.05)$. ${ }^{*} P<0.05$ compared with the control group, ${ }^{\# \# ~} P<0.01$ compared with the resilient group. (d) Adiponectin mRNA in adipose tissue $\left(F_{(2,30)}=9.748, P<0.001\right)$. ${ }^{* * *} P<0.001$ compared with the control group, \#\#\# $P<0.001$ compared with the resilient group. (e) Immunoblots (left) and quantification (right) of adiponectin protein in adipose tissue $\left(F_{(2,30)}=6.945, P<0.01\right)$. ${ }^{* *} P<0.01 \mathrm{compared}$ with the control group, ${ }^{\# \#} P<0.01$ compared with the resilient group. Control, $n=12$; susceptible, $n=10$; resilient, $n=11$. Data are shown as mean \pm s.e.m. 
arms intersect, having a central $5 \times 5-\mathrm{cm}$ square platform giving access to all arms. As described previously, ${ }^{10,11,40,41}$ mice were placed in the central square facing the corner between a closed arm and an open arm and allowed to explore the elevated plus-maze for $5 \mathrm{~min}$. Their activity was videotaped. The numbers of entries made into each arm and the time spent on the open and closed arms were measured. The degree of anxiety was assessed by calculating the percentage of open arm entries (entries into the open arms/total entries into all arms) and percentage of time spent in the open arms (time spent in open arms/total time spent in all arms).

\section{Novelty-suppressed feeding test}

This test is a behavioral model of anxiety based on the conflict between hunger and aversion to a brightly lit, novel environment. The apparatus consisted of a box $(60 \times 60 \times 40 \mathrm{~cm})$ filled with $2 \mathrm{~cm}$ of bedding on the floor. As described previously, ${ }^{10,40}$ a single food pellet was placed on a round filter paper $(11 \mathrm{~cm}$ in diameter) located in the center of the arena. Mice were food-deprived for $24 \mathrm{~h}$ before being placed at the corner of the box and monitored for $10 \mathrm{~min}$. The latency for the animal to approach the food in the center and feed was measured. Immediately after the test, mice were transferred back to their home cage and food consumption was measured for $5 \mathrm{~min}$.

\section{Locomotor activity}

The locomotor activity was measured in an open field box $(40 \times 40 \times 40 \mathrm{~cm})$. Mice were placed in the open field arena and allowed to freely explore for $30 \mathrm{~min} .{ }^{11}$ A charge coupled device camera was mounted above the open box for recording locomotor activity. The total distance traveled was measured in 2-min bins using Any-maze software (Stoelting, Wood Dale, IL, USA).

The experimenters who scored the behaviors were blind to animals' genotypes and treatment conditions.

\section{Western blot assay}

Mice were decapitated rapidly, and trunk blood was collected in tubes containing $20 \mu \mathrm{l}$ of $0.5 \%$ ethylenediaminetetraacetic acid disodium and centrifuged at $1000 \mathrm{~g}$ for $10 \mathrm{~min}$. The supernatant plasma was collected and stored at $-20^{\circ} \mathrm{C}$. The epididymal fat pads were removed, frozen in liquid nitrogen and stored at $-80^{\circ} \mathrm{C}$ before being processed for western blotting. White adipose tissue was homogenized in the lysis buffer (Beyotime Biotechnology, Shanghai, China) with 1\% phenylmethylsulfonyl fluoride (Sangon Biotech, Shanghai, China) and $1 \times$ PhosSTOP phosphatase inhibitor cocktail (Roche Applied Science, Penzberg, Germany). Western blotting was performed as describe elsewhere. ${ }^{31,42,43}$ In brief, adipose tissue lysate or plasma samples were mixed with $5 \times$ sodium dodecyl sulfate-polyacrylamide gel electrophoresis loading dye (Beyotime Biotechnology) and denatured by boiling at $100{ }^{\circ} \mathrm{C}$ for $10 \mathrm{~min}$. Denatured proteins $(20 \mu \mathrm{g}$ adipose tissue lysate or $5 \mu \mathrm{l} 10$-fold diluted plasma sample) were separated on an sodium dodecyl sulfatepolyacrylamide gel electrophoresis and transferred to polyvinylidene fluoride membrane. The membrane was blocked in Tris-buffered saline containing $1 \%$ dried milk and $0.1 \%$ Tween 20 , and then incubated with the following primary antibodies overnight at $4{ }^{\circ} \mathrm{C}$ : anti-adiponectin (Cat. \#AF1119, 1:1000, R\&D systems, Minneapolis, MN, USA), anti-PPARy (Cat. \#sc-7273, 1:500, Santa Cruz Biotechnology, Dallas, TX, USA) and anti- $\beta$-actin (Cat. \#4970, 1:3000, Cell Signaling Technology, Danvers, MA, USA). After washing, membranes were incubated with secondary antibodies: donkey anti-goat IgG (Cat. \#926-32214), donkey anti-mouse IgG (Cat. \#926-68072) and goat anti-rabbit IgG (Cat. \#926-32211) (1:5000, LI-COR Biosciences, Lincoln, NE, USA). Signals were visualized and quantitatively analyzed with Odyssey Sa Quantitative Infrared Imaging System (LI-COR Biosciences). Adiponectin levels were normalized to IgG in plasma and normalized to $\beta$ actin in adipose tissue.

\section{Blood glucose levels}

Trunk blood was collected when mice were decapitated. Blood glucose levels were measured using a glucometer (Bayer HealthCare LLC, Mishawaka, IN, USA).
Real-time RT-PCR

White fat tissue was homogenized and total RNA was extracted with the total RNA rapid extraction kit (Generay Biotechnology, Shanghai, China). HiScript II QRT SuperMix (Vazyme, Nanjing, China) was used to generate cDNA according to following procedure: $1 \mu \mathrm{g}$ of total RNA and $4 \times \mathrm{gDNA}$ Wiper mix were incubated at $42^{\circ} \mathrm{C}$ for $2 \mathrm{~min}$ to remove genome contamination, then $5 \times \mathrm{HiScript}$ II QRT SuperMix was added to the reaction mixture and incubated at $25^{\circ} \mathrm{C}$ for $10 \mathrm{~min}, 50^{\circ} \mathrm{C}$ for $30 \mathrm{~min}$, and $85^{\circ} \mathrm{C}$ for $5 \mathrm{~min}$. The resulting CDNA was used for real-time PCR detection using the StepOnePlus real-time PCR system (Applied Biosystems, Waltham, MA, USA) with AceQ qPCR SYBR green master mix (Vazyme). The condition for PCR was $95^{\circ} \mathrm{C}$ for 5 min, followed by 40 cycles of $95^{\circ} \mathrm{C}$ for $10 \mathrm{~s}$ and $60^{\circ} \mathrm{C}$ for $30 \mathrm{~s}$. The primer sequences used to amplify each product were as follows: mouse Adiponectin, ${ }^{31}$ forward-5'-CAGGCAT CCCAGGACATCC-3', reverse-5'-CCAAGAAGACCTGCATCTCCTIT-3'; mouse PPAR ${ }^{44}{ }^{44}$ forward-5'-ATCTACACGATGCTGGC-3', reverse-5'-GGATGTCCTCGA TGGG-3'; mouse PPARY1, ${ }^{45}$ forward-5'-TTTAAAAACAAGACTACCCTTTACT-3', reverse-5'-AGAGGTCCACAGAGCTGATTCC-3'; mouse PPARY2, ${ }^{45}$ forward5'-GATGCACTGCCTATGAGCACTT-3', reverse-5'-AGAGGTCCACAGAGCTGA TTCC-3'; mouse $\beta$-actin, ${ }^{46}$ forward-5'-GATCATTGCTCCTCCTGAGC-3', reverse- $5^{\prime}$-ACTCCTGCTTGCTGATCCAC- $3^{\prime}$. Samples were run in triplicates and the s.d. was ranged from 0.026 to 0.15 . The $\Delta \Delta C T$ method was used to obtain relative fold-change of target gene expression normalized by the housekeeping gene $\beta$-actin compared with control samples. ${ }^{47} \beta$-actin gene has been validated as a stable and suitable reference gene for gene expression studies, particularly in adipose tissue. ${ }^{48,49} \mathrm{~A}$ plot of the log cDNA dilution versus $\triangle \mathrm{CT}$ (target gene $-\beta$-actin) was made. The absolute values of the slopes (Adiponectin - $\beta$-actin, -0.0094 ; PPARY1 - $\beta$-actin, - 0.027; PPARY2 - $\beta$-actin, 0.0087; PPARY - $\beta$-actin, -0.0199$)$ close to zero confirmed the validity of the $\triangle \triangle C T$ method.

\section{Statistical analyses}

Statistical significance was assessed by one-way analysis of variance (ANOVA), two-way ANOVA, two-way repeated-measures ANOVA or two-tailed $t$-tests, where appropriate. Significant effects in the analysis of variances were followed up with Bonferroni post hoc tests. The linear relationships between two variables were determined by calculating Pearson's correlation coefficient. Results were considered significantly different when $P<0.05$. All data were presented as mean \pm s.e.m.

\section{RESULTS}

Regulation of PPARy and adiponection expression in adipose tissue by chronic social stress

Adult male C57BL/6J mice were defeated daily by different CD1 mice for 10 consecutive days followed by a social interaction test $24 \mathrm{~h}$ after the last defeat session. Mice with a social interaction ratio (ratio of time spent in the interaction zone in the presence versus absence of a social target) $<1$ were defined as susceptible, whereas the mice with a social interaction ratio $>1$ were defined as resilient (Figure 1a). Body weight was measured at the end of the social defeat experiment, which showed no difference between control mice and socially defeated mice (Figure 1a). To identify the involvement of adipose PPARy in susceptibility and resilience to social defeat stress, we measured PPARY mRNA and protein levels in adipose tissue of susceptible and resilient mice in comparison with control mice. Chronic social defeat decreased total PPARY mRNA levels in susceptible mice, but not in resilient subgroup (Figure 1b). Further analysis of PPARY1 and PPARY2 mRNA revealed that levels of PPARY2 mRNA, but not PPARY1 mRNA, were reduced in adipose tissue of susceptible mice compared with control and resilient mice (Figure $1 \mathrm{~b}$ ). Positive correlations were observed between social interaction ratio and total PPARY mRNA or PPARY2 mRNA, but not between social interaction ratio and PPARY1 mRNA, in socially defeated mice (Figure 1b). In parallel with mRNA expression, adipose PPARy protein levels were decreased in susceptible mice (Figure 1c). There was a significant correlation between adipose PPARY protein levels and social interaction behavior (Figure 1c). 
Correspondingly, mRNA and protein levels of adiponectin were decreased in adipose tissue of susceptible mice compared with control and resilient mice (Figures $1 \mathrm{~d}$ and e). These results suggest a functional role of the adipose PPARY and adiponectin in susceptibility and resilience to social defeat stress. a

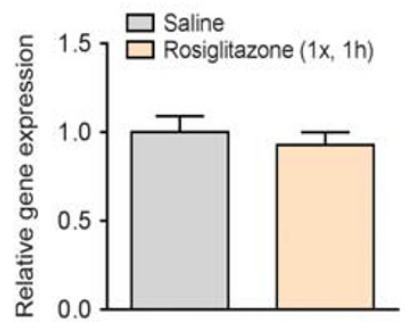

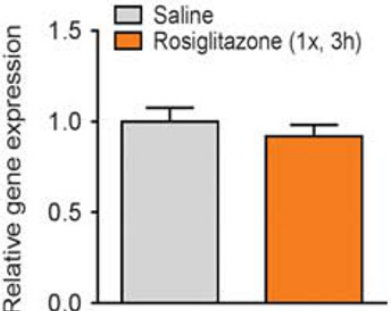
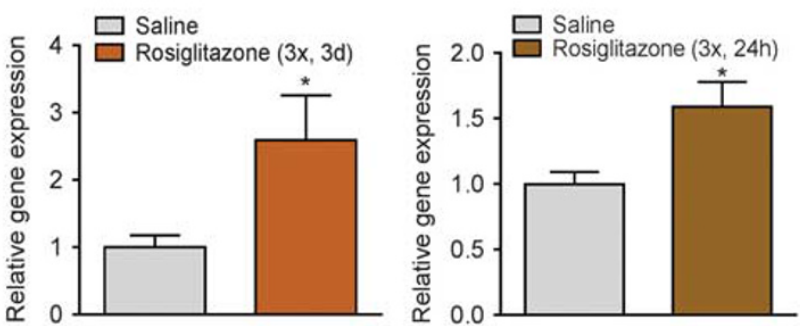

b Adipose adiponectin protein
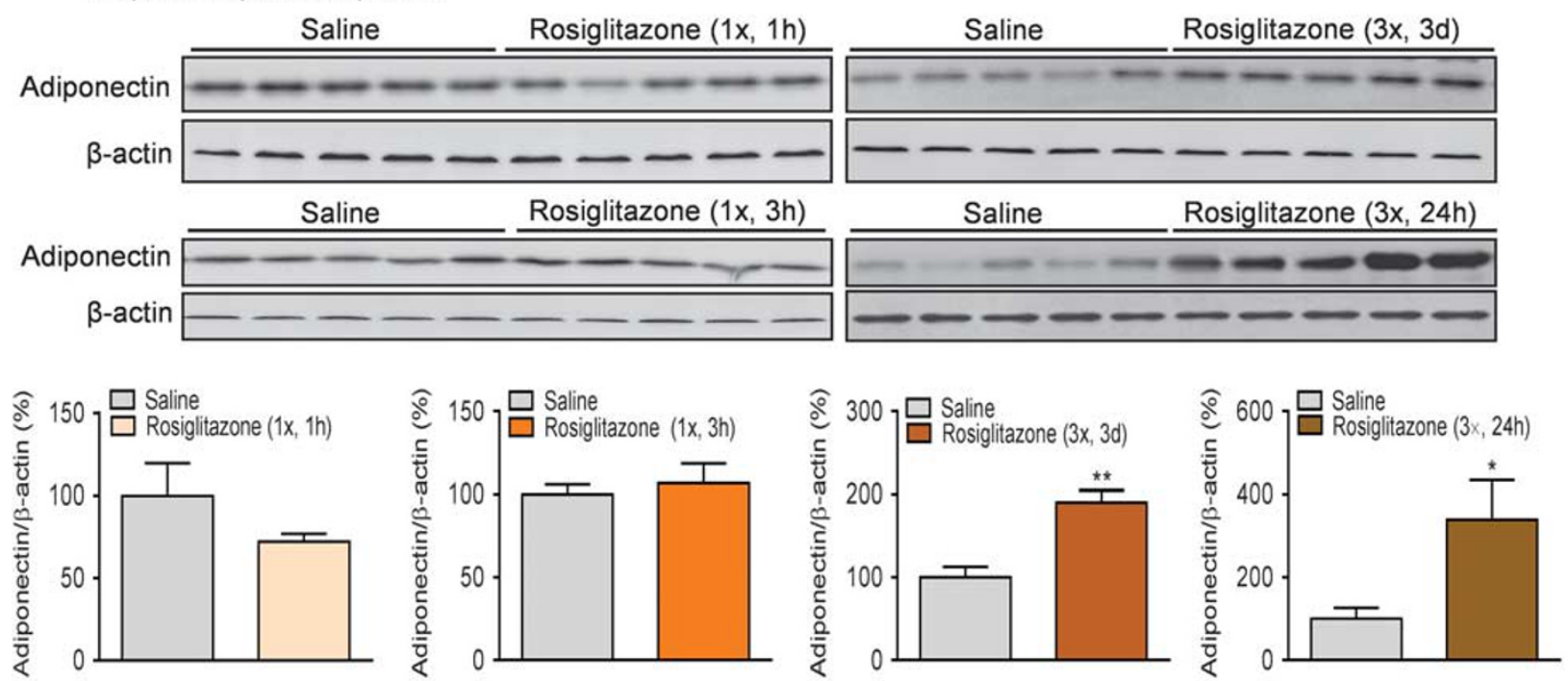

\section{Plasma adiponectin}
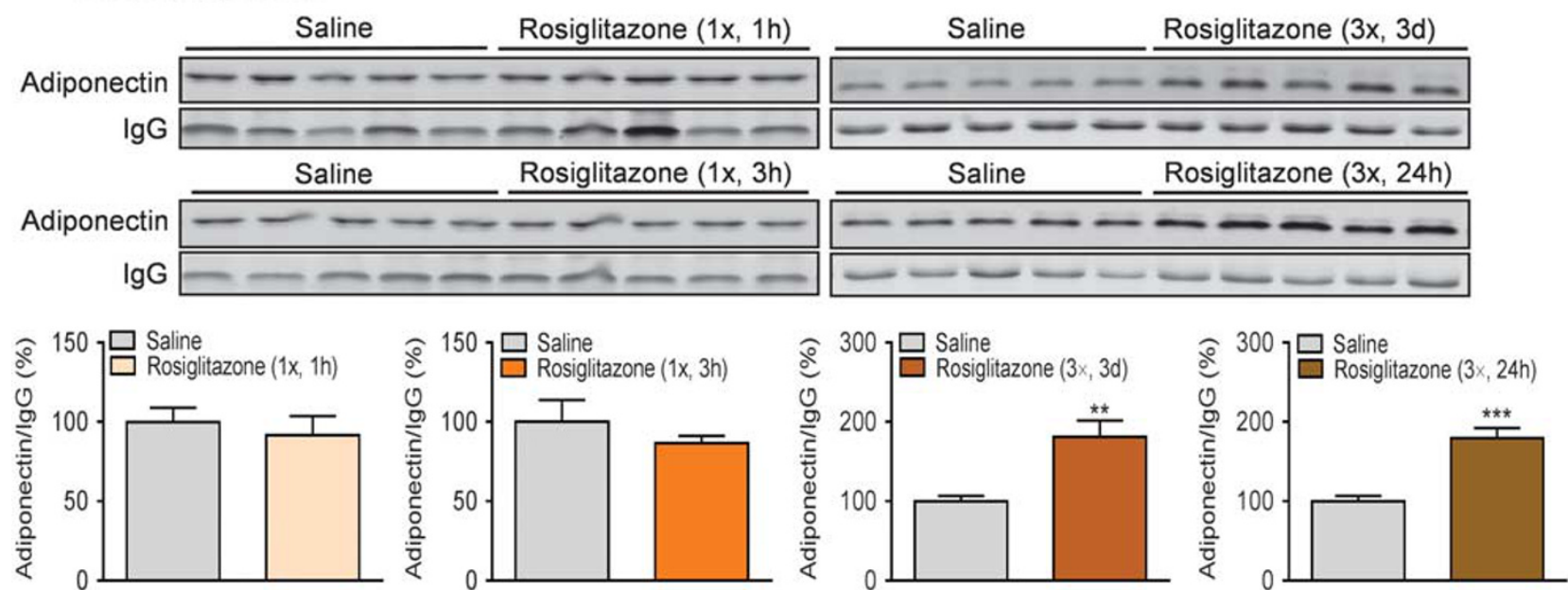

Figure 2. Effects of single and multiple rosiglitazone injections on adiponectin transcription and secretion. (a) Adiponectin mRNA levels in adipose tissue after single ( $1 \mathrm{~h}$ or $3 \mathrm{~h}$ before testing; $1 \times, 1 \mathrm{~h}$ and $1 \times, 3 \mathrm{~h}$ treatments) and three injections of rosiglitazone (10 mg/kg, i.p.) over 3 days $(3 \times, 3 \mathrm{~d})$ or within $24 \mathrm{~h}(3 \times, 24 \mathrm{~h})$. Left: $1 \times, 1 \mathrm{~h} ; t_{(8)}=0.607, P>0.05$. Middle-left: $1 \times, 3 \mathrm{~h} ; t_{(8)}=0.8291, P>0.05$. Middle-right: $3 \times, 3 \mathrm{~d}$; $t_{(8)}=2.306, P<0.05$. Right: $3 \times, 24 \mathrm{~h} ; t_{(8)}=2.777, P<0.05$. (b) Upper, immunoblots of adiponectin protein in adipose tissue. Lower, quantification of adiponectin protein levels. Left: $1 \times, 1 \mathrm{~h} ; t_{(8)}=1.389, P>0.05$. Middle-left: $1 \times, 3 \mathrm{~h} ; t_{(8)}=0.484, P>0.05$. Middle-right: $3 \times, 3 \mathrm{~d}$; $t_{(8)}=4.630, P<0.01$. Right: $\left.3 \times, 24 \mathrm{~h} ; t_{(8)}=2.434, P<0.05\right)$. (c) Upper, immunoblots of plasma adiponectin after single and multiple rosiglitazone injections. Lower, quantification of adiponectin levels (Left: $1 \times, 1 \mathrm{~h} ; t_{(8)}=0.5624, P>0.05$. Middle-left: $1 \times, 3 \mathrm{~h} ; t_{(8)}=0.928$, $P>0.05$. Middle-right: $3 \times, 3 d ; t_{(8)}=3.765, P<0.01$. Right: $3 \times, 24$ h; $\left.t_{(8)}=5.443, P<0.001\right) . n=5$ per group. ${ }^{*} P<0.05,{ }^{* *} P<0.01,{ }^{* * *} P<0.001$ compared with the saline-treated group. Data are shown as mean \pm s.e.m. 


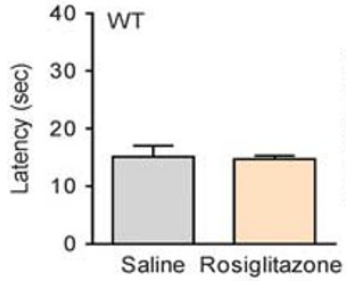

(1x, 1h)

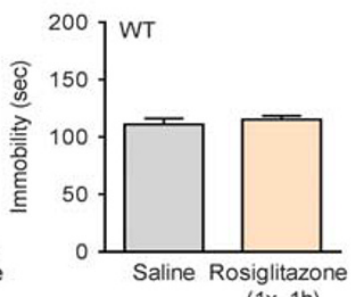

(1x, 1h)
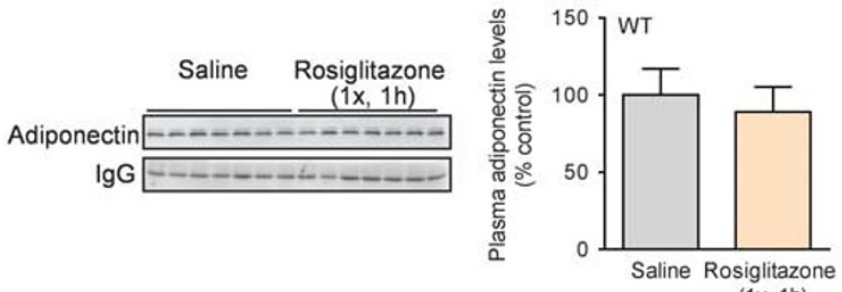

(1x, 1h)

a2

Forced swim test - Rosiglitazone (3x, 24h)

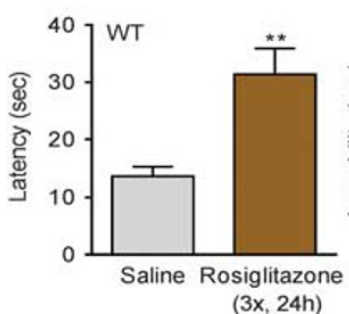

(3x, 24h)

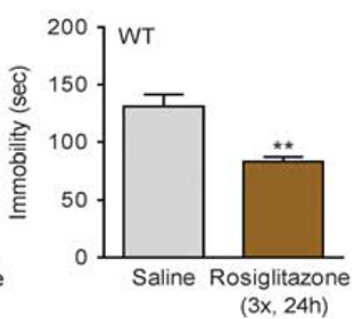

$(3 x, 24 h)$
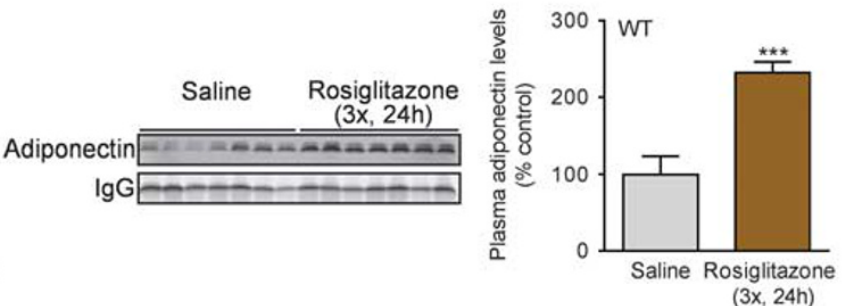

a3

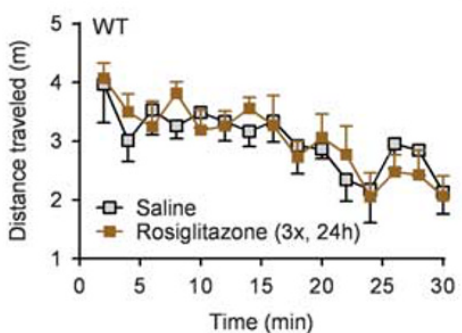

Locomotion - Rosiglitazone (3x, 24h)

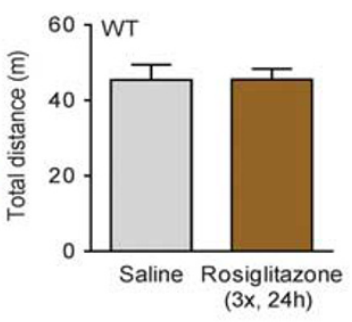

b

Forced swim test - Rosiglitazone (3x, 24h)
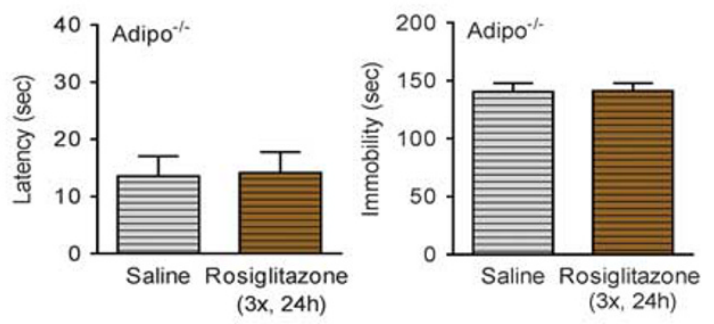

Figure 3. Effects of rosiglitazone on depression-related behaviors in wild-type and Adipo ${ }^{-/-}$mice. All mice were subjected to a 15-min pretest followed $24 \mathrm{~h}$ later by a 6-min forced swim test. (a1) Forced swim test performed $1 \mathrm{~h}$ after a single rosiglitazone injection $(1 \times, 1 \mathrm{~h})$ in wild-type (WT) mice. Left: latency to immobility; $t_{(18)}=0.203, P>0.05$. Middle-left: immobility time; $t_{(18)}=0.707, P>0.05$. Middle-right: immunoblots of plasma adiponectin measured immediately after the test. Right: quantification of plasma adiponectin levels $\left(t_{(18)}=0.461, P>0.05\right) . n=10$ per group. (a2) Forced swim test performed following three injections of rosiglitazone within $24 \mathrm{~h}(3 \times, 24 \mathrm{~h})$ in WT mice. Left: latency to immobility; $t_{(12)}=3.659, P<0.01$. Middle-left: immobility time; $t_{(12)}=4.263, P<0.01$. Middle-right, Immunoblots of plasma adiponectin measured immediately after the test. Right: quantification of plasma adiponectin levels $\left(t_{(12)}=4.777, P<0.001\right)$. $n=7$ per group. (a3) Locomotor activity. Left: time course of locomotor activity after three injections of rosiglitazone within $24 \mathrm{~h}\left(\right.$ time: $F_{(14,182)}=5.990, P<0.001$; treatment: $F_{(1,13)}=0.001, P>0.05$; time $\times$ treatment interaction: $\left.F_{(14,182)}=0.873, P>0.05\right)$. Right: total distance $\left(t_{(13)}=0.032, P>0.05\right)$. Saline,

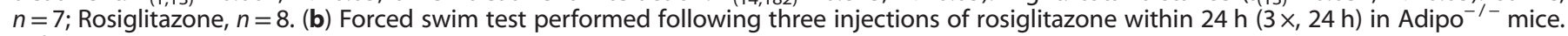
Left: latency to immobility; $t_{(14)}=0.115, P>0.05$. Right: immobility time; $t_{(14)}=0.0739, P>0.05 . n=8$ per group. ${ }^{* *} P<0.01, * * * P<0.001$ compared with the saline-treated group. Data are shown as mean \pm s.e.m.

Effects of PPARy activation on adiponectin levels: single versus multiple rosiglitazone injections

As a direct transcriptional target of PPARy, adiponectin was expected to be upregulated in a relatively short-term frame after treatment with PPARY agonists. We therefore examined adiponectin expression in response to a single and multiple (three times) i.p. injections of rosiglitazone $(10 \mathrm{mg} / \mathrm{kg})$, a highly selective and potent PPARy agonist. ${ }^{50}$ We found that a single i.p. injection failed to increase mRNA and protein expression of adiponectin in adipose tissue or plasma at $1 \mathrm{~h}$ and $3 \mathrm{~h}$ after injection (Figures 2ac). Multiple injections of rosiglitazone, that is, 3 i.p. injections over 3 days (once daily) or within $24 \mathrm{~h}$ (23.5, 3 and $1 \mathrm{~h}$ before blood and tissue collection) significantly increased mRNA levels and protein expression of adiponectin in adipose tissue and plasma adiponectin concentrations (Figures 2a-c). Blood glucose levels were not altered in any of these rosiglitazone treatment groups (Supplementary Figure S1a). Body weight exhibited no significant difference between vehicle and rosiglitazone treatment groups (Supplementary Figure S1b).

Antidepressant-like effect of rosiglitazone is abolished in adiponectin knockout mice

The antidepressant-like effect of rosiglitazone was assessed in a modified forced swim test. Wild-type mice were first subjected to a 15 -min pretest swim session, and next day received a single i.p. injection of rosiglitazone $(10 \mathrm{mg} / \mathrm{kg}) 1 \mathrm{~h}$ before the $6-\mathrm{min}$ test. This rosiglitazone treatment had no effect on the latency and duration of immobility in the forced swim (Figure 3a1). Plasma adiponectin levels measured immediately after the forced swim test showed no significant difference between rosiglitazone- and vehicle-treated groups (Figure 3a1). Next, we tested the multiple injection treatment regimen. After a 15 -min pretest, mice received 3 i.p. injections of rosiglitazone $(10 \mathrm{mg} / \mathrm{kg}) 23.5$, 3 and $1 \mathrm{~h}$ before the testing session. This treatment regimen 


\section{a Elevated plus maze}

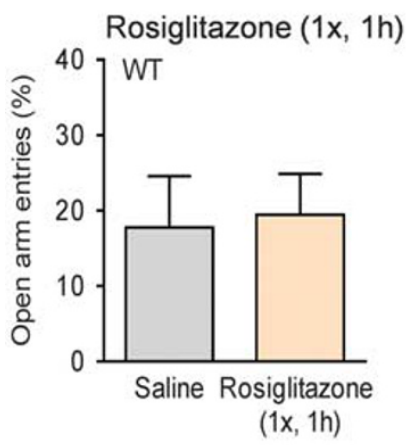

Rosiglitazone (3x, 24h)
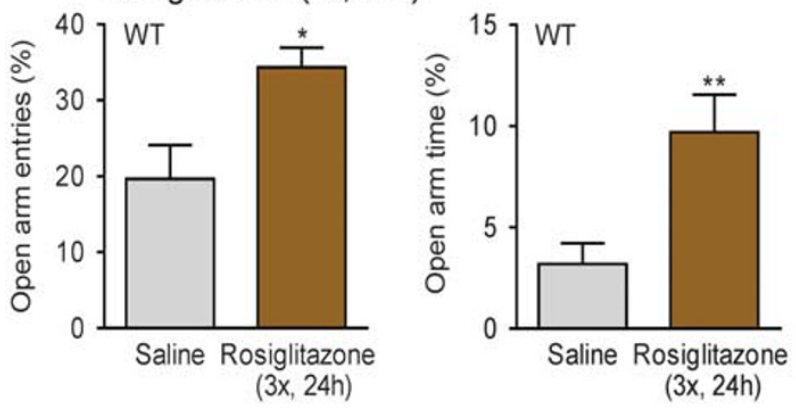

Rosiglitazone (3x, 24h)
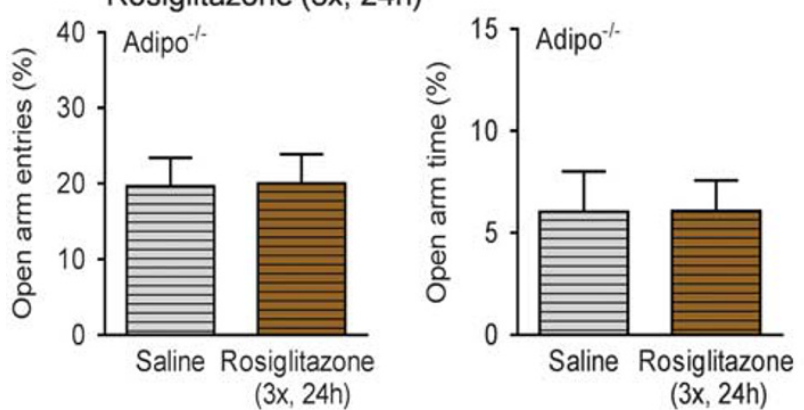

b Novelty-suppressed feeding

Rosiglitazone (3x, 24h)

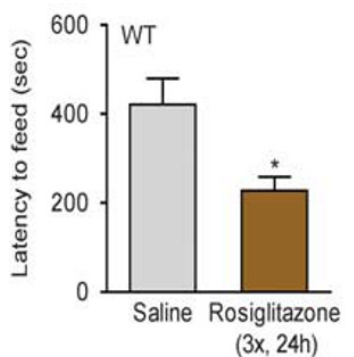

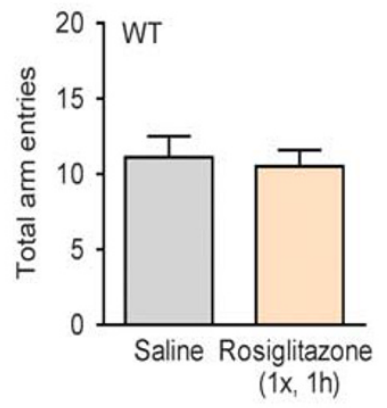
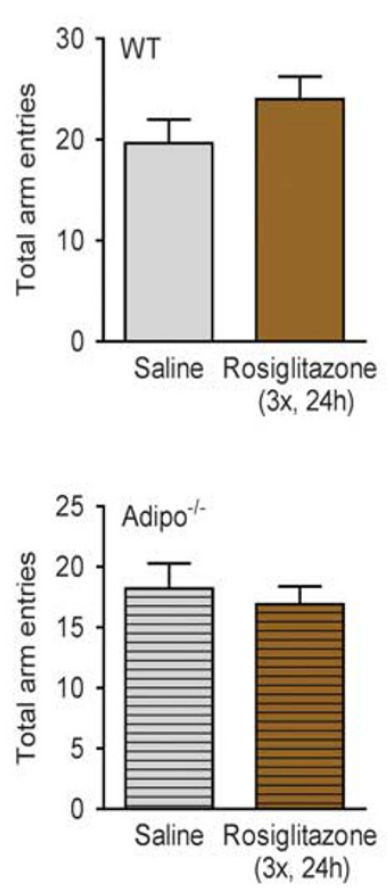

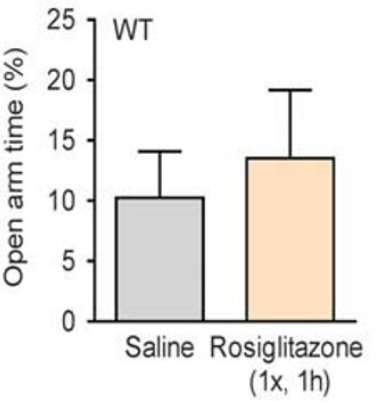

Rosiglitazone (3x, 24h)
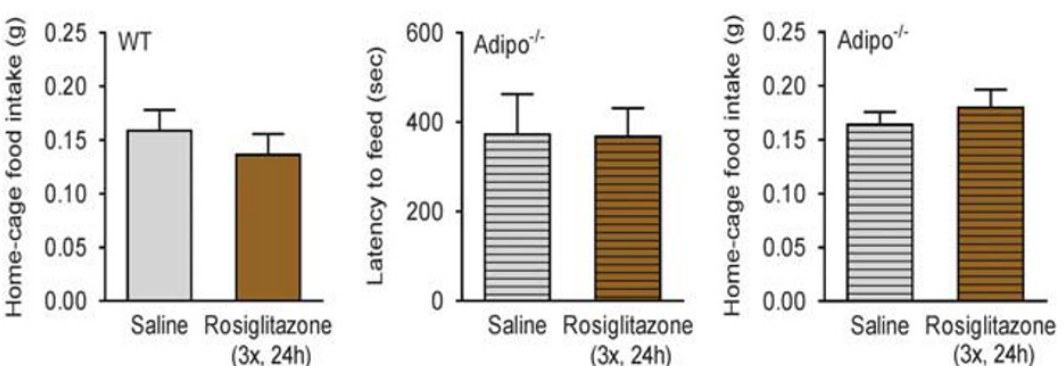

Figure 4. Effects of rosiglitazone on anxiety-related behaviors in wild-type and Adipo ${ }^{-1-}$ mice. (a) Upper, elevated plus-maze test performed $1 \mathrm{~h}$ after a single rosiglitazone injection $(1 \times, 1 \mathrm{~h})$ in wild-type (WT) mice (Upper-left: percentage of open arm entries; $t_{(18)}=0.192, P>0.05$; upper-middle: percentage of open arm time; $t_{(18)}=0.480, P>0.05$; upper-right: total arm entries; $\left.t_{(18)}=0.3369, P>0.05\right)$. $n=10$ per group. Middle, elevated plus-maze test performed in WT mice following three rosiglitazone injections within $24 \mathrm{~h}(3 \times, 24 \mathrm{~h})$. Middle-left: percentage of open arm entries; $t_{(14)}=2.837, P<0.05$. Middle-middle: percentage of open arm time; $t_{(14)}=3.044, P<0.01$. Middle-right: total arm entries; $t_{(14)}=1.348, P>0.05$. $n=8$ per group. Lower, elevated plus-maze test performed in Adipo ${ }^{-/-}$mice following three rosiglitazone injections within $24 \mathrm{~h}(3 \times, 24 \mathrm{~h})$. Lower-left: percentage of open arm entries; $t_{(18)}=0.0719, P>0.05$. Lower-middle: percentage of open arm time; $t_{(18)}=0.0116, P>0.05$. Lower-right: total arm entries; $t_{(18)}=0.5084, P>0.05 . n=10$ per group. (b) Novelty-suppressed feeding test following three rosiglitazone injections within $24 \mathrm{~h}$ in WT mice and Adipo ${ }^{-\prime}$ mice. Left, latency to feed of WT mice $\left(t_{(14)}=2.915, P<0.05\right)$. Middle-left, home-cage food consumption of WT mice $\left(t_{(14)}=0.8228, P>0.05\right) . n=8$ per group. Middle-right, latency to feed of Adipo ${ }^{-1-}$ mice $\left(t_{(14)}=0.0466, P>0.05\right)$. Right, home-cage food consumption of Adipo ${ }^{-1-}$ mice $\left(t_{(14)}=0.799, P>0.05\right)$. $n=8$ per group. ${ }^{*} P<0.05,{ }^{* *} P<0.01$ compared with the saline-treated group. Data are shown as mean \pm s.e.m. 
significantly increased the latency to immobility and reduced immobility duration in the forced swim test, accompanied by an increase in plasma adiponectin levels measured after the test (Figure 3a2). Given that increased locomotor activity could confound the interpretation of results from the forced swim test, we examined the locomotor response to rosiglitazone in an open field. Mice that received 3 i.p. injections of rosiglitazone $(10 \mathrm{mg} / \mathrm{kg} ; 23.5,3$ and $1 \mathrm{~h})$ or vehicle showed no difference in the distance traveled during the $30 \mathrm{~min}$ test (Figure 3a3).

To determine whether increased adiponectin levels contribute to the rosiglitazone-induced antidepressant-like effect, adiponectin knockout (Adipo ${ }^{-1-}$ ) mice received the same treatment with multiple rosiglitazone injections after a pretest. In the absence of adiponectin, rosiglitazone failed to induce significant change in either latency or duration of immobility in the forced swim test (Figure 3b), suggesting that adiponectin is necessary for the antidepressant-like effect of rosiglitazone. Moreover, we compared $\mathrm{Adipo}^{-/-}$mice with wild-type littermate controls in the forced swim test. Under basal conditions, $\mathrm{Adipo}^{-/-}$mice demonstrated immobility levels that were comparable to wild-type littermate controls (Supplementary Figure S2a).

\section{Anxiolytic effects of rosiglitazone are abolished in adiponectin} knockout mice

To evaluate whether rosiglitazone regulates anxiety-related behavior, wild-type mice received a single i.p. injection $(10 \mathrm{mg} /$ kg) $1 \mathrm{~h}$ before a 5-min elevated plus-maze test. No effect was observed on the entries made into open arms or the time spent on open arms (Figure 4a). However, multiple rosiglitazone injections (23.5, 3 and $1 \mathrm{~h}$ before the test) significantly increased the percentage of open-arm entries and open-arm time (Figure 4a), suggesting an anxiolytic-like effect. This effect of rosiglitazone was abolished in Adipo ${ }^{-/-}$mice (Figure 4a). Under basal conditions Adipo ${ }^{-1-}$ mice exhibited no differences in open arm entries and open arm time compared with wild-type littermate control mice (Supplementary Figure S2b). Furthermore, we examined the anxiolytic effect of rosiglitazone in the noveltysuppressed feeding test, another behavioral model of anxiety. Mice were first deprived of food for $24 \mathrm{~h}$ and then received 3 i.p. injections of rosiglitazone 23.5, 3 and $1 \mathrm{~h}$ before measuring the latency for the animal to approach a food pellet located in the center of an open area. In wild-type mice, rosiglitazone significantly decreased the latency of wild-type mice to feed without affecting home-cage food consumption within $5 \mathrm{~min}$ immediately after the test (Figure 4b). However, this effect of rosiglitazone was absent in Adipo $^{-/-}$mice (Figure $4 b$ ). These data suggest that the anxiolytic-like effects of rosiglitazone requires the presence of adiponectin.

PPARy expression is unaltered in adiponectin knockout mice

One possibility for the absence of antidepressant- and anxiolyticlike effects of rosiglitazone in Adipo $^{-/-}$mice could result from downregulation of PPARY due to adiponectin deficiency. To address this, levels of total PPARY, PPARY1 and PPARY2 mRNA were measured in adipose tissue. There were no differences in mRNA levels for PPARY, PPARY1 and PPARY2 between Adipo ${ }^{-/-}$mice and littermate control mice (Supplementary Figure S3a). In addition, we determined the effects of adiponectin deficiency on PPARY1 and PPARY2 mRNA expression in the brain. Only PPARY1 mRNA was detected in the brain, such as the hippocampus and prefrontal cortex. In both brain regions, Adipo $^{-/-}$mice and wildtype littermate controls showed comparable levels of PPARY1 mRNA expression (Supplementary Figure S3b). These data indicate that PPARy expression in adipose tissue and brain is not affected in $\mathrm{Adipo}^{-}{ }^{-}$mice.
Rosiglitazone-induced increase in adiponectin production is PPAR $\gamma$-dependent

Rosiglitazone has been shown to exert both PPARY-dependent and PPARY-independent effects on metabolism. ${ }^{51}$ To examine whether the effect of rosiglitazone on adiponectin levels is dependent on PPARY activation, GW9662, a selective PPARY antagonist, was administered to mice $30 \mathrm{~min}$ before each rosiglitazone injection, which was given $23.5,3$ and $1 \mathrm{~h}$ before blood and tissue collection. Blockade of PPARy with GW9662 significantly attenuated the effects of rosiglitazone on adiponectin mRNA and protein levels in adipose tissue (Figure 5a1). Correspondingly, pretreatment with GW9662 also blocked the rosiglitazone-induced increase in plasma adiponectin levels (Figure 5a2).

Effects of rosiglitazone on depression- and anxiety-related behaviors are PPAR $y$-dependent

To confirm that the rosiglitazone-induced antidepressant-like effect is PPARy-dependent, mice were first subjected to a 15-min pretest and then pretreated with GW9662 30 min before each rosiglitazone injection that was given 23.5, 3 and $1 \mathrm{~h}$ before the forced swim test. Although GW9662 alone had no effect on immobility in this test, it blocked the rosiglitazone-induced increase in latency to immobility and decrease in immobility duration (Figure 5b). To test that whether the anxiolytic-like effects of rosiglitazone are dependent on PPAR $\gamma$, mice received the same pretreatment with GW9662 and treatment with rosiglitazone followed by a 5-min elevated plus-maze test. The rosiglitazoneinduced increase in open-arm entries and open-arm time was antagonized by GW9662 (Figure 5c). In the novelty-suppressed feeding test, pretreatment with GW9662 attenuated the effect of rosiglitazone on latency to feed without changing home-cage food consumption (Figure $5 \mathrm{~d}$ ). These results suggest that PPAR $\gamma$ activation is responsible for the antidepressant/anxiolytic-like effects of rosiglitazone.

\section{DISCUSSION}

In this study we aimed to uncover a novel role for adipose PPARY in stress susceptibility and negative emotional behaviors. We show that chronic social defeat stress decreased PPAR $y$ mRNA and protein levels in adipose tissue of susceptible but not resilient mice, which coincided with social avoidance behavior. A parallel decrease in adiponectin production was observed in adipose tissue of susceptible mice, which is consistent with the role of PPARY as the key transcription factor controlling adiponectin expression. ${ }^{19,24}$ We further show that PPARy activation by rosiglitazone increased adiponectin production and produced antidepressant- and anxiolytic-like effects. Adiponectin is essential for PPARy-mediated effects on depression- and anxiety-related behaviors.

The PPARY gene generates two isoforms, PPARY1 and PPARY2, by alternative splicing and promoter usage. ${ }^{15,52}$ They differ in their $\mathrm{N}$ terminal protein sequence. PPARY2 contains 30 extra amino acids on the $\mathrm{N}$-terminus, ${ }^{15}$ which confer a $5-10$-fold increase in transcription-stimulating activity. ${ }^{53}$ In this study, we found that PPARY1 and PPARY2 were differentially regulated in adipose tissue in relation to vulnerability and resilience to chronic social defeat stress. Susceptible mice showed significant decrease in mRNA levels of total PPARY and PPARY2 but not PPARY1 compared with control and resilient mice. Consistent with the mRNA results, PPARy protein levels in adipose tissue was also reduced in susceptible mice but not in resilient mice. As a transcription factor, the reduction of PPARy activity was expected to inhibit expression of the target genes. ${ }^{5,55}$ Indeed, both mRNA and protein levels of adiponectin in adipose tissue were found to be decreased by chronic social defeat in susceptible mice but not in the resilient 
subgroup. These findings suggest that suppression of the adipose PPARY-adiponectin axis activity may participate in determining susceptibility and resilience to stress. This notion was further supported by our previous finding that adiponectin insufficiency increases susceptibility to social defeat stress. ${ }^{31}$ However, what mechanisms mediate social defeat-induced PPARy downregulation is currently unknown. One possibility would be an overactive state of the sympathetic nervous system induced by chronic social defeat stress. ${ }^{56,57}$ Sympathetic nerve fibers directly innervate white adipose tissue and release norepinephrine at neuro-adipose
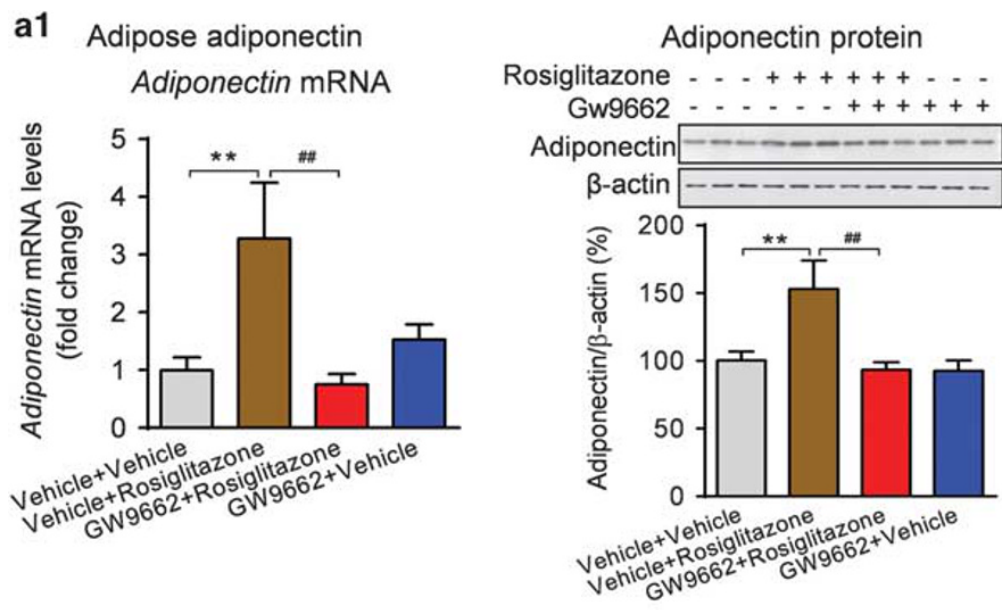

a2 Plasma adiponectin

Rosiglitazone - - - + + + + + + - .

Gw9662 - . - . . + +++++

Adiponectin $-\ldots \ldots \ldots$
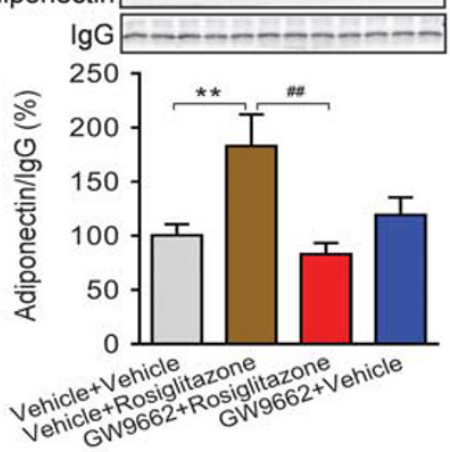

\section{b Forced swim test}
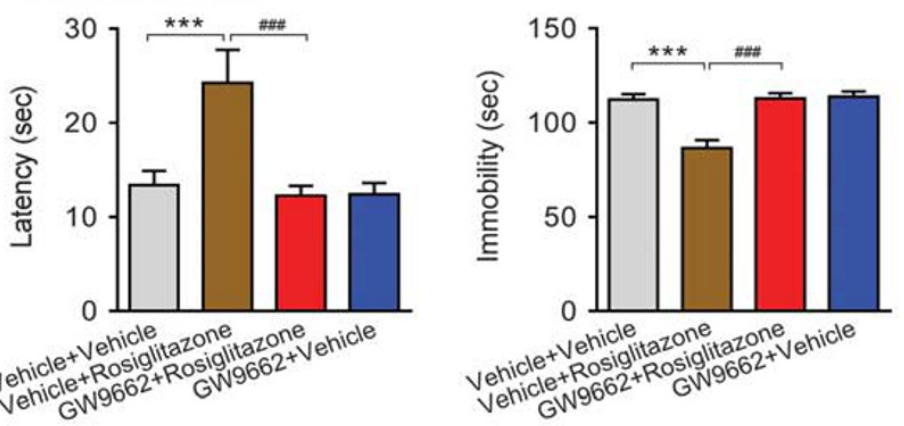

\section{Elevated plus maze}
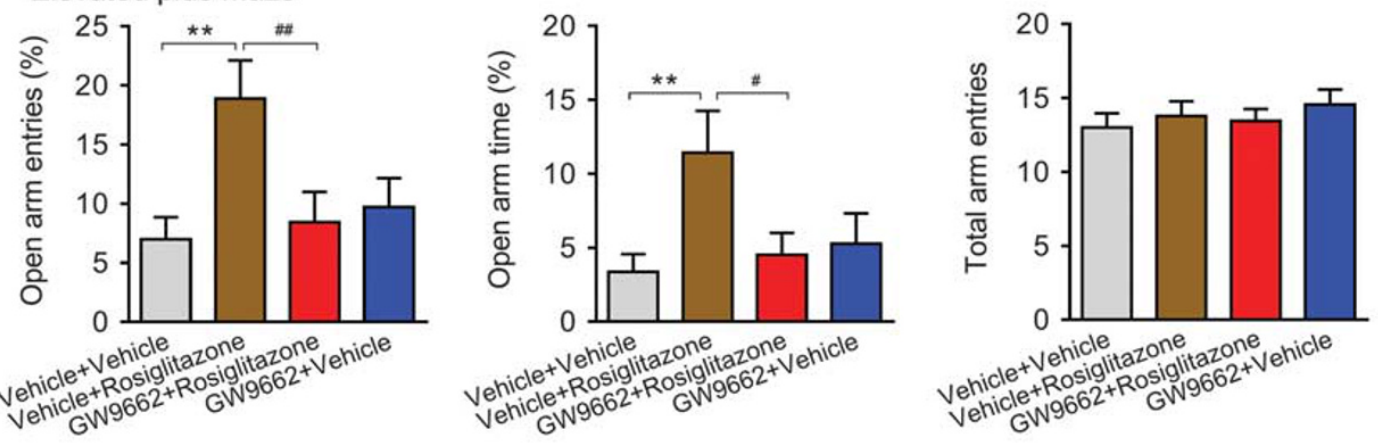

\section{d Novelty-suppressed feeding}
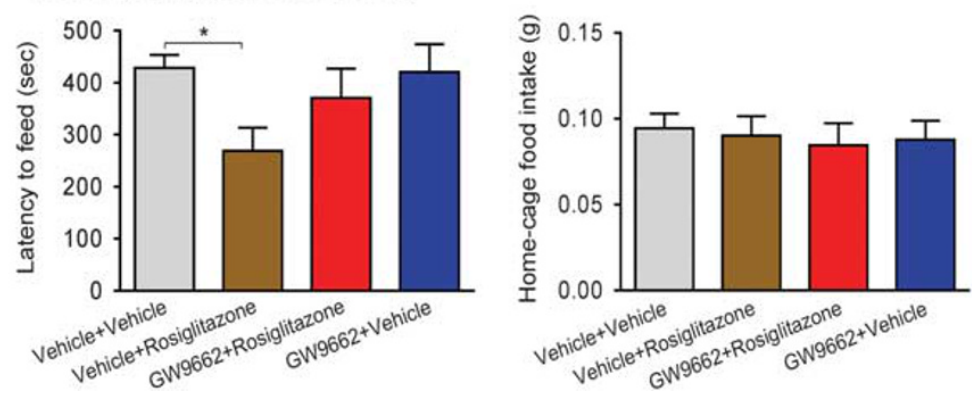
junctions. ${ }^{58,59}$ It has been reported that norepinephrine represses PPARY2 gene expression in adipocytes. ${ }^{60}$ An overactive sympathetic nervous system and elevated norepinephrine levels in adipose tissue under chronic stress may lead to PPARY downregulation.

The selective agonists for PPAR $\gamma$, including rosiglitazone and pioglitazone, are currently prescribed for the treatment of type 2 diabetes. ${ }^{50,61}$ They have been widely used as a pharmacological tool for defining the functions of PPAR $y .{ }^{62}$ Previous studies have shown that rosiglitazone increases adiponectin levels after 7 days to 15 week of i.p. or oral administration. ${ }^{26,63,64}$ These studies, however, cannot rule out the possibility that induction of adiponectin may occur secondary, at least in part, to body weight reduction and metabolic syndrome alleviation due to chronic treatment with rosiglitazone. ${ }^{65,66}$ In the present study, we determined the effects of a single and multiple injections of rosiglitazone on adiponectin levels within a relatively short-time frame. Although a single i.p. injection failed to elevate adiponectin levels in adipose tissue and plasma $1 \mathrm{~h}$ or $3 \mathrm{~h}$ after injection, multiple injections within $24 \mathrm{~h}(23.5,3$ and $1 \mathrm{~h})$ or in 3 consecutive days significantly increased adiponectin mRNA and protein expression in adipose tissue and plasma levels without altering glucose concentrations and body weight. This suggests that rosiglitazone-induced adiponectin production precedes its metabolic actions.

Both the single and multiple i.p. injection treatment regimens have been used to test the efficacy of antidepressants in the forced swim test in rodents. ${ }^{67}$ We found that multiple injections of rosiglitazone (within $24 \mathrm{~h}$ ), but not the single injection treatment, significantly reduced immobility, an index of behavioral 'despair', in the forced swim test. This is generally consistent with a previous report showing that oral administration of rosiglitazone for 5 days decreases immobility in rats and mice. ${ }^{36}$ Furthermore, we found that the antidepressant-like effect of rosiglitazone was associated with increased circulating adiponectin levels measured immediately after the forced swim test. The time lag between rosiglitazone treatment and antidepressant-like behavioral effects may be explained by the time required to induce adiponectin synthesis/secretion and achieve an effective concentration. Our investigations with Adipo $^{-/-}$mice confirmed that adiponectin is necessary for the antidepressant-like effects of rosiglitazone. Similarly, we found that rosiglitazone elicited anxiolytic-like effects the elevated plus-maze and novelty-suppressed feeding tests. These anxiolytic-like effects of rosiglitazone also require the presence of adiponectin. Given the fact that adiponectin is expressed exclusively in adipose tissue ${ }^{22}$ and our observation of the blockade of behavioral responses to rosiglitazone by pretreatment with the selective PPARY antagonist GW9662, we propose that the antidepressant/anxiolytic-like effects of rosiglitazone are dependent on activation of PPARY in adipose tissue through the induction of adiponectin. Adiponectin exists in different oligomers in the circulation, that is, trimers, hexamers and high-molecular-weight multimers. ${ }^{68,69}$ Trimers and hexamers can cross the BBB and detected in the cerebrospinal fluid of humans and mice. ${ }^{70-72}$ Two adiponectin receptors, AdipoR1 and AdipoR2, are found to be highly expressed in brain regions implicated in depression and anxiety disorders, such as the hippocampus and prefrontal cortex, ${ }^{8,31}$ where adiponectin may exert its antidepressant- and anxiolytic effects.

We chose to use rosiglitazone to activate PPARY in this study because this drug is thought to be impermeable to the intact BBB in rodents, thus confining its effects to peripheral tissues. ${ }^{73,74}$ Rosiglitazone is a substrate of P-glycoprotein, a major drug efflux transporter in the $\mathrm{BBB}^{75}$ which limits its penetration into the brain. ${ }^{76}$ However, under certain circumstances, neurological insults such as Alzheimer's disease and stroke can cause breakdown of the BBB, which increases permeability of the BBB to rosiglitazone. ${ }^{77,78}$ Studies have suggested that activation of brain PPARy produces antidepressant-like effects. Direct infusion of rosiglitazone into the brain reduces immobility time in the forced swim test. ${ }^{79}$ Pioglitazone, another PPARy agonist that can cross the BBB, also elicit antidepressant-like effects. ${ }^{37}$ The question is then raised whether activation of brain PPAR may contribute to the antidepressant/anxiolytic-like effects induced by peripherally administered rosiglitazone. The absence of antidepressant/anxiolytic-like effects of rosiglitazone in Adipo $^{-/-}$mice, however, ruled out this possibility. Adipo ${ }^{-1-}$ mice showed normal PPARy expression levels in the brain. If brain PPARy is involved in mediating rosiglitazone-induced behavioral effects, one would expect that rosiglitazone remains to be effective in Adipo $^{-/-}$mice in the forced swim test and the elevated plus-maze test. Moreover, we demonstrated that PPARy expression was unaltered in adipose tissue of Adipo ${ }^{-1-}$ mice, suggesting that the unresponsiveness of $\mathrm{Adipo}^{-/-}$mice to rosiglitazone is not due to downregulation of adipose PPARY. The use of conditional knockout mice with tissuespecific deletion of PPARY will help to further clarify the role of PPARY in adipose tissue in stress responses and emotion-related behaviors.

Depressive disorders are highly prevalent, along with the growing epidemic of obesity and type 2 diabetes. Despite the well-established association between these conditions, ${ }^{1,80-83}$ the underlying causes remain to be identified. Both PPAR $p$ and adiponectin are important players in the pathogenesis of obesity and type 2 diabetes. The development of obesity requires the continuous differentiation of new adipocytes, which is controlled by PPARy. ${ }^{17,18}$ Adiponectin levels are reduced in obese and type 2

Figure 5. Effects of GW9662 on rosiglitazone-induced adiponectin expression and antidepressant- and anxiolytic-like behavioral responses in wild-type mice. (a1) Adipose adiponectin mRNA and protein levels. Left, adiponectin mRNA levels (pretreatment: $F_{(1,16)}=3.641, P<0.05$; treatment: $F_{(1,16)}=2.050, P>0.05$; interaction: $\left.F_{(1,19)}=8.506, P<0.05\right)$. Right, representative immunoblots and quantification of adiponectin protein expression (pretreatment: $F_{(1,16)}=7.783, P<0.05$; treatment: $F_{(1,16)}=4.895, P<0.05$; interaction: $\left.F_{(1,16)}=4.678, P<0.05\right) . n=5$ per group. (a2) Plasma adiponectin. Representative immunoblots and quantification of plasma adiponectin levels (pretreatment: $F_{(1,16)}=5.017$, $P<0.05$; treatment: $F_{(1,16)}=1.640, P>0.05$; interaction: $\left.F_{(1,16)}=10.705, P<0.05\right)$. $n=5$ per group. (b) Forced swim test. Left, latency to immobility (pretreatment: $F_{(1,28)}=9.754, P<0.01$; treatment: $F_{(1,28)}=6.690, P<0.05$; interaction: $\left.F_{(1,28)}=7.102, P<0.05\right)$. Right, immobility time (pretreatment: $F_{(1,28)}=17.939, P<0.001$; treatment: $F_{(1,28)}=16.331, P<0.001$; interaction: $\left.F_{(1,28)}=14.190, P<0.001\right)$. $n=8$ per group. (c) Elevated plus-maze test. Left, percentage of open arm entries (pretreatment: $F_{(1,32)}=2.237, P>0.05$; treatment: $F_{(132)}=4.234, P<0.05$; interaction: $\left.F_{(1,32)}=6.571, P<0.05\right)$. Middle, percentage of open arm time (pretreatment: $F_{(1,32)}=1.584, P>0.05 ;$ treatment: $F_{(1,32)}=3.356$, $P>0.05$; interaction: $\left.F_{(1,32)}=4.854, P<0.05\right)$. Right, total arm entries (pretreatment: $F_{(1,32)}=0.417, P>0.05$; treatment: $F_{(1,32)}=0.031$, $P>0.05$; interaction: $\left.F_{(1,32)}=0.996, P>0.05\right) . n=9$ per group. (d) Novelty-suppressed feeding test. Left, latency to feed (pretreatment: $F_{(1,32)}=1.004$, $P>0.05$; treatment: $F_{(1,32)}=5.059, P<0.05$; interaction: $\left.F_{(1,32)}=1.390, P>0.05\right)$. Right, home-cage food consumption in 5 min after the test (pretreatment: $F_{(1,32)}=0.304, P>0.05$; treatment: $F_{(1,32)}=0.123, P>0.05$; interaction: $\left.F_{(1,32)}=0.003, P>0.05\right)$. $n=9$ per group. ${ }^{*} P<0.05$, ${ }^{* *} P<0.01,{ }^{* * *} P<0.001$ compared with the Vehicle+Vehicle treatment group; ${ }^{\#} P<0.05$, ${ }^{\#} P<0.01$, ${ }^{\# \# \#} P<0.001$ compared with the Vehicle + Rosiglitazone treatment group. Data are shown as mean \pm s.e.m. 
diabetes patients. ${ }^{84-87}$ These findings, together with our current observation of downregulation of adipose PPARy and adiponectin in the chronic stress model of depression and our previous finding of adiponectin insufficiency increasing susceptibility for stressinduced depressive-like behavior, ${ }^{31}$ suggest that PPARy and adiponectin dysregulation may be the shared common biological pathways for obesity, type 2 diabetes and depression. The PPARY agonists and other stimulators of adiponectin used for diabetes and metabolic syndrome may be effective against depression.

In conclusion, the present study provide evidence for a novel role of adipose PPARy in susceptibility and resilience to chronic stress and a functional link between PPARy and adiponectin in mediating emotion-related behaviors. Our results suggest that the PPARY-adiponectin axis is involved, not only in maintaining metabolic homeostasis but also in maintaining emotional homeostasis under stress. Given that the BBB presents a real challenge in drug development for neuropsychiatric disorders, our findings implicate that PPARy and its targets in adipose tissue may be a promising pharmacological target to combat depression, anxiety, and other stress-related disorders.

\section{CONFLICT OF INTEREST}

The authors declare no conflict of interest.

\section{ACKNOWLEDGMENTS}

This work was supported by the National Natural Science Foundation of China (81301164 to MG; 81301182 to SX) and the National Institute of Mental Health (MH096251 and MH076929 to X-YL).

\section{REFERENCES}

1 Golden SH, Lazo M, Carnethon M, Bertoni AG, Schreiner PJ, Diez Roux AV et al. Examining a bidirectional association between depressive symptoms and diabetes. JAMA 2008; 299: 2751-2759.

2 Kahl KG, Schweiger U, Correll C, Muller C, Busch ML, Bauer M et al. Depression, anxiety disorders, and metabolic syndrome in a population at risk for type 2 diabetes mellitus. Brain Behav 2015; 5: e00306.

3 Deng Y, Scherer PE. Adipokines as novel biomarkers and regulators of the metabolic syndrome. Ann N Y Acad Sci 2010; 1212: E1-E19.

4 Harvey J. Leptin regulation of neuronal excitability and cognitive function. Curr Opin Pharmacol 2007; 7: 643-647.

5 Garza JC, Guo M, Zhang W, Lu XY. Leptin increases adult hippocampal neurogenesis in vivo and in vitro. J Biol Chem 2008; 283: 18238-18247.

6 Garza JC, Guo M, Zhang W, Lu XY. Leptin restores adult hippocampal neurogenesis in a chronic unpredictable stress model of depression and reverses glucocorticoid-induced inhibition of GSK-3beta/beta-catenin signaling. Mol Psychiatry 2012; 17: 790-808.

7 Zhang D, Guo M, Zhang W, Lu XY. Adiponectin stimulates proliferation of adult hippocampal neural stem/progenitor cells through activation of p38 mitogenactivated protein kinase (p38MAPK)/glycogen synthase kinase 3beta (GSK-3beta)/ beta-catenin signaling cascade. J Biol Chem 2011; 286: 44913-44920.

8 Zhang D, Wang X, Lu XY. Adiponectin exerts neurotrophic effects on dendritic arborization, spinogenesis, and neurogenesis of the dentate gyrus of male mice. Endocrinology 2016; 157: 2853-2869.

9 Zhang D, Wang X, Wang B, Garza JC, Fang X, Wang J et al. Adiponectin regulates contextual fear extinction and intrinsic excitability of dentate gyrus granule neurons through AdipoR2 receptors. Mol Psychiatry 2016; e-pub ahead of print 3 May 2016; doi: 10.1038/mp.2016.58.

10 Liu J, Perez SM, Zhang W, Lodge DJ, Lu XY. Selective deletion of the leptin receptor in dopamine neurons produces anxiogenic-like behavior and increases dopaminergic activity in amygdala. Mol Psychiatry 2011; 16: 1024-1038.

11 Guo M, Lu Y, Garza JC, Li Y, Chua SC, Zhang W et al. Forebrain glutamatergic neurons mediate leptin action on depression-like behaviors and synaptic depression. Transl Psychiatry 2012; 2: e83.

12 Pinto S, Roseberry AG, Liu H, Diano S, Shanabrough M, Cai X et al. Rapid rewiring of arcuate nucleus feeding circuits by leptin. Science 2004; 304: 110-115.

13 Bouret SG, Draper SJ, Simerly RB. Trophic action of leptin on hypothalamic neurons that regulate feeding. Science 2004; 304: 108-110.

14 Berger J, Moller DE. The mechanisms of action of PPARs. Annu Rev Med 2002; 53 : 409-435.
15 Zhu Y, Qi C, Korenberg JR, Chen XN, Noya D, Rao MS et al. Structural organization of mouse peroxisome proliferator-activated receptor gamma (mPPAR gamma) gene: alternative promoter use and different splicing yield two mPPAR gamma isoforms. Proc Natl Acad Sci USA 1995; 92: 7921-7925.

16 Vidal-Puig A, Jimenez-Linan M, Lowell BB, Hamann A, Hu E, Spiegelman B et al. Regulation of PPAR gamma gene expression by nutrition and obesity in rodents. J Clin Invest 1996; 97: 2553-2561.

17 Rosen ED, Sarraf P, Troy AE, Bradwin G, Moore K, Milstone DS et al. PPAR gamma is required for the differentiation of adipose tissue in vivo and in vitro. Mol Cell 1999; 4: 611-617.

18 Barak Y, Nelson MC, Ong ES, Jones YZ, Ruiz-Lozano P, Chien KR et al. PPAR gamma is required for placental, cardiac, and adipose tissue development. Mol Cell 1999; 4: $585-595$.

19 Iwaki M, Matsuda M, Maeda N, Funahashi T, Matsuzawa Y, Makishima M et al. Induction of adiponectin, a fat-derived antidiabetic and antiatherogenic factor, by nuclear receptors. Diabetes 2003; 52: 1655-1663.

20 Hollenberg AN, Susulic VS, Madura JP, Zhang B, Moller DE, Tontonoz P et al. Functional antagonism between CCAAT/Enhancer binding protein-alpha and peroxisome proliferator-activated receptor-gamma on the leptin promoter. J Biol Chem 1997; 272: 5283-5290.

21 Tomaru T, Steger DJ, Lefterova MI, Schupp M, Lazar MA. Adipocyte-specific expression of murine resistin is mediated by synergism between peroxisome proliferator-activated receptor gamma and CCAAT/enhancer-binding proteins. J Biol Chem 2009; 284: 6116-6125.

22 Scherer PE, Williams S, Fogliano M, Baldini G, Lodish HF. A novel serum protein similar to C1q, produced exclusively in adipocytes. J Biol Chem 1995; 270: 26746-26749.

$23 \mathrm{Hu}$ E, Liang P, Spiegelman BM. AdipoQ is a novel adipose-specific gene dysregulated in obesity. J Biol Chem 1996; 271: 10697-10703.

24 Maeda N, Takahashi M, Funahashi T, Kihara S, Nishizawa H, Kishida K et al. PPARgamma ligands increase expression and plasma concentrations of adiponectin, an adipose-derived protein. Diabetes 2001; 50: 2094-2099.

25 Choi JH, Banks AS, Estall JL, Kajimura S, Bostrom P, Laznik D et al. Anti-diabetic drugs inhibit obesity-linked phosphorylation of PPARgamma by Cdk5. Nature 2010; 466: 451-456.

26 Combs TP, Wagner JA, Berger J, Doebber T, Wang WJ, Zhang BB et al. Induction of adipocyte complement-related protein of 30 kilodaltons by PPARgamma agonists: a potential mechanism of insulin sensitization. Endocrinology 2002; 143: 998-1007.

27 Wong WT, Tian XY, Xu A, Yu J, Lau CW, Hoo RL et al. Adiponectin is required for PPARgamma-mediated improvement of endothelial function in diabetic mice. Cell Metab 2011; 14: 104-115.

28 Lee $\mathrm{CH}$, Olson P, Evans RM. Minireview: lipid metabolism, metabolic diseases, and peroxisome proliferator-activated receptors. Endocrinology 2003; 144: 2201-2207.

29 Nawrocki AR, Rajala MW, Tomas E, Pajvani UB, Saha AK, Trumbauer ME et al. Mice lacking adiponectin show decreased hepatic insulin sensitivity and reduced responsiveness to peroxisome proliferator-activated receptor gamma agonists. J Biol Chem 2006; 281: 2654-2660.

30 Kubota N, Terauchi Y, Kubota T, Kumagai H, Itoh S, Satoh H et al. Pioglitazone ameliorates insulin resistance and diabetes by both adiponectin-dependent and -independent pathways. J Biol Chem 2006; 281: 8748-8755.

31 Liu J, Guo M, Zhang D, Cheng SY, Liu M, Ding J et al. Adiponectin is critical in determining susceptibility to depressive behaviors and has antidepressant-like activity. Proc Natl Acad Sci USA 2012; 109: 12248-12253.

32 Krishnan V, Han MH, Graham DL, Berton O, Renthal W, Russo SJ et al. Molecular adaptations underlying susceptibility and resistance to social defeat in brain reward regions. Cell 2007; 131: 391-404.

33 Berton O, McClung CA, Dileone RJ, Krishnan V, Renthal W, Russo SJ et al. Essential role of BDNF in the mesolimbic dopamine pathway in social defeat stress. Science 2006; 311: 864-868.

34 Yu T, Guo M, Garza J, Rendon S, Sun XL, Zhang W et al. Cognitive and neural correlates of depression-like behaviour in socially defeated mice: an animal model of depression with cognitive dysfunction. Int J Neuropsychopharmacol 2011; 14: 303-317.

35 Yau SY, Li A, Hoo RL, Ching YP, Christie BR, Lee TM et al. Physical exercise-induced hippocampal neurogenesis and antidepressant effects are mediated by the adipocyte hormone adiponectin. Proc Natl Acad Sci USA 2014; 111: 15810-15815.

36 Eissa Ahmed AA, Al-Rasheed NM, Al-Rasheed NM. Antidepressant-like effects of rosiglitazone, a PPARgamma agonist, in the rat forced swim and mouse tail suspension tests. Behav Pharmacol 2009; 20: 635-642.

37 Sadaghiani MS, Javadi-Paydar M, Gharedaghi MH, Fard YY, Dehpour AR. Antidepressant-like effect of pioglitazone in the forced swimming test in mice: the role of PPAR-gamma receptor and nitric oxide pathway. Behav Brain Res 2011; 224: $336-343$. 
38 Lu XY, Kim CS, Frazer A, Zhang W. Leptin: a potential novel antidepressant. Proc Natl Acad Sci USA 2006; 103: 1593-1598.

39 Rodgers RJ, Dalvi A. Anxiety, defence and the elevated plus-maze. Neurosci Biobehav Rev 1997; 21: 801-810.

40 Liu J, Guo M, Lu XY. Leptin/LepRb in the ventral tegmental area mediates anxietyrelated behaviors. Int J Neuropsychopharmacol 2016; 19: 2.

41 Liu J, Garza JC, Bronner J, Kim CS, Zhang W, Lu XY. Acute administration of leptin produces anxiolytic-like effects: a comparison with fluoxetine. Psychopharmacology (Berl) 2010; 207: 535-545.

42 Wang $X$, Zhang D, Lu XY. Dentate gyrus-CA3 glutamate release/NMDA transmission mediates behavioral despair and antidepressant-like responses to leptin. Mol Psychiatry 2015; 20: 509-519.

43 Guo M, Lu XY. Leptin receptor deficiency confers resistance to behavioral effects of fluoxetine and desipramine via separable substrates. Transl Psychiatry 2014; 4: e486.

44 Son NH, Park TS, Yamashita H, Yokoyama M, Huggins LA, Okajima K et al. Cardiomyocyte expression of PPARgamma leads to cardiac dysfunction in mice. J Clin Invest 2007; 117: 2791-2801.

45 Jitrapakdee S, Slawik M, Medina-Gomez G, Campbell M, Wallace JC, Sethi JK et al. The peroxisome proliferator-activated receptor-gamma regulates murine pyruvate carboxylase gene expression in vivo and in vitro. $J$ Biol Chem 2005; 280: 27466-27476.

46 Wang Z, Yang L, Jiang Y, Ling ZQ, Li Z, Cheng Y et al. High fat diet induces formation of spontaneous liposarcoma in mouse adipose tissue with overexpression of interleukin 22. PLoS One 2011; 6: e23737.

47 Livak KJ, Schmittgen TD. Analysis of relative gene expression data using real-time quantitative PCR and the 2(-Delta Delta C(T)) Method. Methods 2001; 25: 402-408.

48 Mehta R, Birerdinc A, Hossain N, Afendy A, Chandhoke V, Younossi Z et al. Validation of endogenous reference genes for qRT-PCR analysis of human visceral adipose samples. BMC Mol Biol 2010; 11: 39.

49 Suzuki T, Higgins PJ, Crawford DR. Control selection for RNA quantitation. Biotechniques 2000; 29: 332-337.

50 Lehmann JM, Moore LB, Smith-Oliver TA, Wilkison WO, Willson TM, Kliewer SA. An antidiabetic thiazolidinedione is a high affinity ligand for peroxisome proliferator-activated receptor gamma (PPAR gamma). J Biol Chem 1995; 270: 12953-12956.

51 Step SE, Lim HW, Marinis JM, Prokesch A, Steger DJ, You SH et al. Anti-diabetic rosiglitazone remodels the adipocyte transcriptome by redistributing transcription to PPARgamma-driven enhancers. Genes Dev 2014; 28: 1018-1028.

52 Fajas L, Auboeuf D, Raspe E, Schoonjans K, Lefebvre AM, Saladin R et al. The organization, promoter analysis, and expression of the human PPARgamma gene. J Biol Chem 1997; 272: 18779-18789.

53 Werman A, Hollenberg A, Solanes G, Bjorbaek C, Vidal-Puig AJ, Flier JS. Ligand-independent activation domain in the $\mathrm{N}$ terminus of peroxisome proliferator-activated receptor gamma (PPARgamma). Differential activity of PPARgamma1 and -2 isoforms and influence of insulin. $J$ Biol Chem 1997; 272: 20230-20235.

54 Jones JR, Barrick C, Kim KA, Lindner J, Blondeau B, Fujimoto $\mathrm{Y}$ et al. Deletion of PPARgamma in adipose tissues of mice protects against high fat diet-induced obesity and insulin resistance. Proc Natl Acad Sci USA 2005; 102: 6207-6212.

55 Imai T, Takakuwa R, Marchand S, Dentz E, Bornert JM, Messaddeq N et al. Peroxisome proliferator-activated receptor gamma is required in mature white and brown adipocytes for their survival in the mouse. Proc Natl Acad Sci USA 2004; 101: 4543-4547.

56 Reader BF, Jarrett BL, McKim DB, Wohleb ES, Godbout JP, Sheridan JF. Peripheral and central effects of repeated social defeat stress: monocyte trafficking, microglial activation, and anxiety. Neuroscience 2015; 289: 429-442.

57 McKim DB, Niraula A, Tarr AJ, Wohleb ES, Sheridan JF, Godbout JP. Neuroinflammatory Dynamics Underlie Memory Impairments after Repeated Social Defeat. J Neurosci 2016; 36: 2590-2604.

58 Bowers RR, Festuccia WT, Song CK, Shi H, Migliorini RH, Bartness TJ. Sympathetic innervation of white adipose tissue and its regulation of fat cell number. Am J Physiol Regul Integr Comp Physiol 2004; 286: R1167-R1175.

59 Zeng W, Pirzgalska RM, Pereira MM, Kubasova N, Barateiro A, Seixas E et al. Sympathetic neuro-adipose connections mediate leptin-driven lipolysis. Cell 2015; 163: 84-94.

60 Lindgren EM, Nielsen R, Petrovic N, Jacobsson A, Mandrup S, Cannon B et al. Noradrenaline represses PPAR (peroxisome-proliferator-activated receptor) gamma2 gene expression in brown adipocytes: intracellular signalling and effects on PPARgamma2 and PPARgamma1 protein levels. Biochem J 2004; 382: 597-606.
61 Forman BM, Tontonoz P, Chen J, Brun RP, Spiegelman BM, Evans RM. 15-Deoxydelta 12,14 -prostaglandin $\mathrm{J} 2$ is a ligand for the adipocyte determination factor PPAR gamma. Cell 1995; 83: 803-812.

62 Choi JH, Banks AS, Kamenecka TM, Busby SA, Chalmers MJ, Kumar $\mathrm{N}$ et al. Antidiabetic actions of a non-agonist PPARgamma ligand blocking Cdk5mediated phosphorylation. Nature 2011; 477: 477-481.

63 Strum JC, Shehee R, Virley D, Richardson J, Mattie M, Selley P et al. Rosiglitazone induces mitochondrial biogenesis in mouse brain. J Alzheimers Dis 2007; 11: 45-51.

64 Takasawa K, Kubota N, Terauchi Y, Kadowaki T. Impact of increased PPARgamma activity in adipocytes in vivo on adiposity, insulin sensitivity and the effects of rosiglitazone treatment. Endocr J 2008; 55: 767-776.

65 Tsuchida A, Yamauchi T, Takekawa S, Hada Y, Ito Y, Maki T et al. Peroxisome proliferator-activated receptor (PPAR)alpha activation increases adiponectin receptors and reduces obesity-related inflammation in adipose tissue: comparison of activation of PPARalpha, PPARgamma, and their combination. Diabetes 2005; 54: 3358-3370.

66 Le Bouter S, Rodriguez M, Guigal-Stephan N, Courtade-Gaiani S, Xuereb L, de Montrion $\mathrm{C}$ et al. Coordinate transcriptomic and metabolomic effects of the insulin sensitizer rosiglitazone on fundamental metabolic pathways in liver, soleus muscle, and adipose tissue in diabetic db/db mice. PPAR Res 2010; 2010: pii: 679184.

67 Cryan JF, Valentino RJ, Lucki I. Assessing substrates underlying the behavioral effects of antidepressants using the modified rat forced swimming test. Neurosci Biobehav Rev 2005; 29: 547-569.

68 Pajvani UB, Du X, Combs TP, Berg AH, Rajala MW, Schulthess T et al. Structurefunction studies of the adipocyte-secreted hormone Acrp30/adiponectin. Implications fpr metabolic regulation and bioactivity. I Biol Chem 2003; 278: 9073-9085.

69 Waki H, Yamauchi T, Kamon J, Ito Y, Uchida S, Kita S et al. Impaired multimerization of human adiponectin mutants associated with diabetes. Molecular structure and multimer formation of adiponectin. J Biol Chem 2003; 278: 40352-40363.

70 Kubota N, Yano W, Kubota T, Yamauchi T, Itoh S, Kumagai H et al. Adiponectin stimulates AMP-activated protein kinase in the hypothalamus and increases food intake. Cell Metab 2007; 6: 55-68.

71 Kusminski CM, McTernan PG, Schraw T, Kos K, O'Hare JP, Ahima R et al. Adiponectin complexes in human cerebrospinal fluid: distinct complex distribution from serum. Diabetologia 2007; 50: 634-642.

72 Neumeier M, Weigert J, Buettner R, Wanninger J, Schaffler A, Muller AM et al. Detection of adiponectin in cerebrospinal fluid in humans. Am J Physiol Endocrinol Metab 2007; 293: E965-E969.

73 Watson GS, Cholerton BA, Reger MA, Baker LD, Plymate SR, Asthana S et al. Preserved cognition in patients with early Alzheimer disease and amnestic mild cognitive impairment during treatment with rosiglitazone: a preliminary study. Am J Geriatr Psychiatry 2005; 13: 950-958.

74 Festuccia WT, Oztezcan S, Laplante M, Berthiaume M, Michel C, Dohgu S et al. Peroxisome proliferator-activated receptor-gamma-mediated positive energy balance in the rat is associated with reduced sympathetic drive to adipose tissues and thyroid status. Endocrinology 2008; 149: 2121-2130.

75 Schinkel AH. P-Glycoprotein, a gatekeeper in the blood-brain barrier. Adv Drug Deliv Rev 1999; 36: 179-194.

76 Hemauer SJ, Patrikeeva SL, Nanovskaya TN, Hankins GD, Ahmed MS. Role of human placental apical membrane transporters in the efflux of glyburide, rosiglitazone, and metformin. Am J Obstet Gynecol 2010; 202: 383 e381-e387.

77 Landreth G, Jiang Q, Mandrekar S, Heneka M. PPARgamma agonists as therapeutics for the treatment of Alzheimer's disease. Neurotherapeutics 2008; 5: 481-489.

78 Collino M, Aragno M, Mastrocola R, Gallicchio M, Rosa AC, Dianzani $C$ et al. Modulation of the oxidative stress and inflammatory response by PPAR-gamma agonists in the hippocampus of rats exposed to cerebral ischemia/reperfusion. Eur J Pharmacol 2006; 530: 70-80.

79 Rosa AO, Kaster MP, Binfare RW, Morales S, Martin-Aparicio E, Navarro-Rico ML et al. Antidepressant-like effect of the novel thiadiazolidinone NP031115 in mice. Prog Neuropsychopharmacol Biol Psychiatry 2008; 32: 1549-1556.

80 Rosmond R, Lapidus L, Bjorntorp P. The influence of occupational and social factors on obesity and body fat distribution in middle-aged men. Int J Obes Relat Metab Disord 1996; 20: 599-607.

81 Richardson LP, Davis R, Poulton R, McCauley E, Moffitt TE, Caspi A et al. A longitudinal evaluation of adolescent depression and adult obesity. Arch Pediatr Adolesc Med 2003; 157: 739-745.

82 Bornstein SR, Schuppenies A, Wong ML, Licinio J. Approaching the shared biology of obesity and depression: the stress axis as the locus of gene-environment interactions. Mol Psychiatry 2006; 11: 892-902. 
83 Lee SH, Paz-Filho G, Mastronardi C, Licinio J, Wong ML. Is increased antidepressant exposure a contributory factor to the obesity pandemic? Transl Psychiatry 2016; 6: e759.

84 Arita Y, Kihara S, Ouchi N, Takahashi M, Maeda K, Miyagawa J et al. Paradoxical decrease of an adipose-specific protein, adiponectin, in obesity. Biochem Biophys Res Commun 1999; 257: 79-83.

85 Kern PA, Di Gregorio GB, Lu T, Rassouli N, Ranganathan G. Adiponectin expression from human adipose tissue: relation to obesity, insulin resistance, and tumor necrosis factor-alpha expression. Diabetes 2003; 52: 1779-1785.

86 Yamauchi T, Kamon J, Waki H, Terauchi Y, Kubota N, Hara K et al. The fat-derived hormone adiponectin reverses insulin resistance associated with both lipoatrophy and obesity. Nat Med 2001; 7: 941-946.

87 Weyer C, Funahashi T, Tanaka S, Hotta K, Matsuzawa Y, Pratley RE et al. Hypoadiponectinemia in obesity and type 2 diabetes: close association with insulin resistance and hyperinsulinemia. J Clin Endocrinol Metab 2001; 86: 1930-1935.

(i)(5) This work is licensed under a Creative Commons AttributionNonCommercial-ShareAlike 4.0 International License. The images or other third party material in this article are included in the article's Creative Commons license, unless indicated otherwise in the credit line; if the material is not included under the Creative Commons license, users will need to obtain permission from the license holder to reproduce the material. To view a copy of this license, visit http:// creativecommons.org/licenses/by-nc-sa/4.0/

(c) The Author(s) 2017

Supplementary Information accompanies the paper on the Molecular Psychiatry website (http://www.nature.com/mp). 